Research Paper

\title{
Systematic revelation of the protective effect and mechanism of Cordycep sinensis on diethylnitrosamine-induced rat hepatocellular carcinoma with proteomics
}

\author{
Pei-Wen Wang ${ }^{1}$, Yu-Chiang Hung ${ }^{1,2}$, Wen-Tai Li ${ }^{3}$, Chau-Ting Yeh4 ${ }^{4}$ Tai-Long Pan ${ }^{1,4,5,6}$ \\ ${ }^{1}$ School of Traditional Chinese Medicine, Chang Gung University, Taoyuan, Taiwan \\ ${ }^{2}$ Department of Chinese Internal Medicine, Chang Gung Memorial Hospital-Kaohsiung Medical Center, Kaohsiung City, Taiwan \\ ${ }^{3}$ National Research Institute of Chinese Medicine, Ministry of Health and Welfare, Taipei, Taiwan \\ ${ }^{4}$ Liver Research Center, Chang Gung Memorial Hospital, Taoyuan, Taiwan \\ ${ }^{5}$ Research Center for Industry of Human Ecology, Chang Gung University of Science and Technology, Taoyuan, Taiwan \\ ${ }^{6}$ Department of Medical Research, China Medical University Hospital, China Medical University, Taichung, Taiwan \\ Correspondence to: Tai-Long Pan, email: pan@mail.cgu.edu.tw \\ Keywords: diethylnitrosamine, hepatocellular carcinoma, Cordycep sinensis, proteomics \\ Received: January 09, 2016 \\ Accepted: July 18, 2016 \\ Published: August 11, 2016
}

\section{ABSTRACT}

Cordyceps sinensis ( $C$. sinensis) has been reported to treat liver diseases. Here, we investigated the inhibitory effect of $C$. sinensis on hepatocarcinoma in a diethylnitrosamine (DEN)-induced rat model with functional proteome tools.

In the DEN-exposed group, levels of serum alanine aminotransferase and aspartate aminotransferase were increased while $C$. sinensis application remarkably inhibited the activities of these enzymes. Histopathological analysis also indicated that $C$. sinensis could substantially restore hypertrophic hepatocytes caused by DEN, suggesting that $C$. sinensis is effective in preventing DEN-induced hepatocarcinogenesis.

We therefore comprehensively delineated the global protein alterations using a proteome platform. The most meaningful changes were found among proteins involved in oxidative stress and detoxification. Meanwhile, $C$. sinensis application could attenuate the carbonylation level of several enzymes as well as chaperone proteins. Network analysis implied that $C$. sinensis could obviously alleviate hepatocarcinoma via modulating redox imbalance, protein ubiquitination and tumor growth-associated transcription factors.

Our findings provide new insight into the potential effects of $C$. sinensis in preventing carcinogenesis and might help in developing novel therapeutic strategies against chemical-induced hepatocarcinoma.

\section{INTRODUCTION}

Hepatocellular carcinoma (HCC) is one of the most common types of malignant tumors and the third leading cause of cancer death worldwide [1]. In spite of current advances in the use of synthetic drugs, several shortcomings such as efficacy and side effects still remain [2]. Thus, there is an urgent need for alternative and effective agents for the management of hepatocellular carcinoma, with better efficacy and less detriment [3]. The major causes of HCC are known as hepatitis B or
$\mathrm{C}$ virus infection and alcohol exposure [4, 5]. Recent studies have indicated that formation of reactive oxygen species (ROS) within hepatocytes would eventually result in the cytotoxic effect [6]. Furthermore, ROS-caused oxidation of target proteins or enzymes would negatively influence their normal functions, which might lead to hepatocarcinogenesis [7]. Compelling evidences also showed that ROS could promote the invasive ability of hepatoma cells [8]. Therefore, simultaneous treatment with antioxidants, especially at the early stages, might be a breakthrough in $\mathrm{HCC}$ interventions. 
Cordyceps sinensis (C. sinensis), a parasitic fungus growing on the larvae of Lepidoptera, has been used as a Chinese herbal medicine to cure numerous diseases [9]. It possesses anti-tumor, antioxidant activity and the capability of improving immune responses [10-12]. Recent reports have shown that the methanolic extracts of C. sinensis exhibited a significant anti-proliferation effect against several cancer cell lines, including $\mathrm{HepG}_{2}$ cells [13-15]. Despite the effect as a free radical scavenger, the underlying mechanism for the therapeutic or protective effect of $C$. sinensis upon HCC is still not clarified and remains to be elucidated. Our study is the first report to systematically analyze the alterations of global protein profiles as well as the protein oxidative modification that reflect the anti-cancer efficacy and signaling cascades of C. sinensis with high throughput proteome tools combined with bioinformatics.

Diethylnitrosamine (DEN) is a component of tobacco smoke, fried foods, cheese, and a number of alcoholic beverages. The formation of alkyl DNA adducts, by which (8-hydroxy-2'-deoxyguanosine (8-OHdG)) consequently blocks replication, has been considered the predominant factor in DEN-mediated tumorigenesis [16]. In addition, the administration of DEN was proven to enhance the formation of the activated oxygen species in the preneoplastic nodules in the liver [17]. In the present study, DEN-induced hepatocellular carcinoma in a rat model has been used to reveal the molecular mechanisms by which $C$. sinensis might prevent the growth of human hepatocellular carcinoma. Carcinogenesis is a multistep process involved in complicated protein changes in response to environmental cues. We used two-dimensional (2-DE) gel electrophoresis combined with MALDI-TOF identification and network analysis to thoroughly delineate the differential protein profiles as well as the signaling pathways.

Meanwhile, DEN treatment disturbs the normal redox balance and shifts hepatocytes into a state of highly oxidative stress, which induces the carbonylation of specific groups of proteins involved in the progression of liver tumors [18, 19]. The most widely studied oxidative stress-induced modification of proteins is the formation of carbonyl groups that can react with 2,4-dinitrophenylhydrazine (DNP) and are detected by specific antibodies [20,21]. We applied redox proteomics to prove our hypothesis concerning the anti-tumor effect of $C$. sinensis. These tools allow us to investigate the proteins involved in the multiple signaling cascades of the living cell, and to provide an unbiased approach to uncover new players controlling cell function, especially in tumor carcinogenesis and therapy [22, 23].

The purpose of the present study is to verify our hypothesis that $C$. sinensis could attenuate the oxidative stress induced by DEN and protect the liver from hepatoma. Moreover, characterization of the associated molecular mechanisms would improve the clinical utility of herbal intervention in liver cancer therapy.

\section{RESULTS}

\section{Characteristics of pure compounds from C. sinensis extract}

The constituents were determined with narrowbore HPLC procedure by comparing the retention time with reference standard. Three major compounds of C. sinensis were identified as follows: uridine, adenosine and ergosterol (Figure 1).

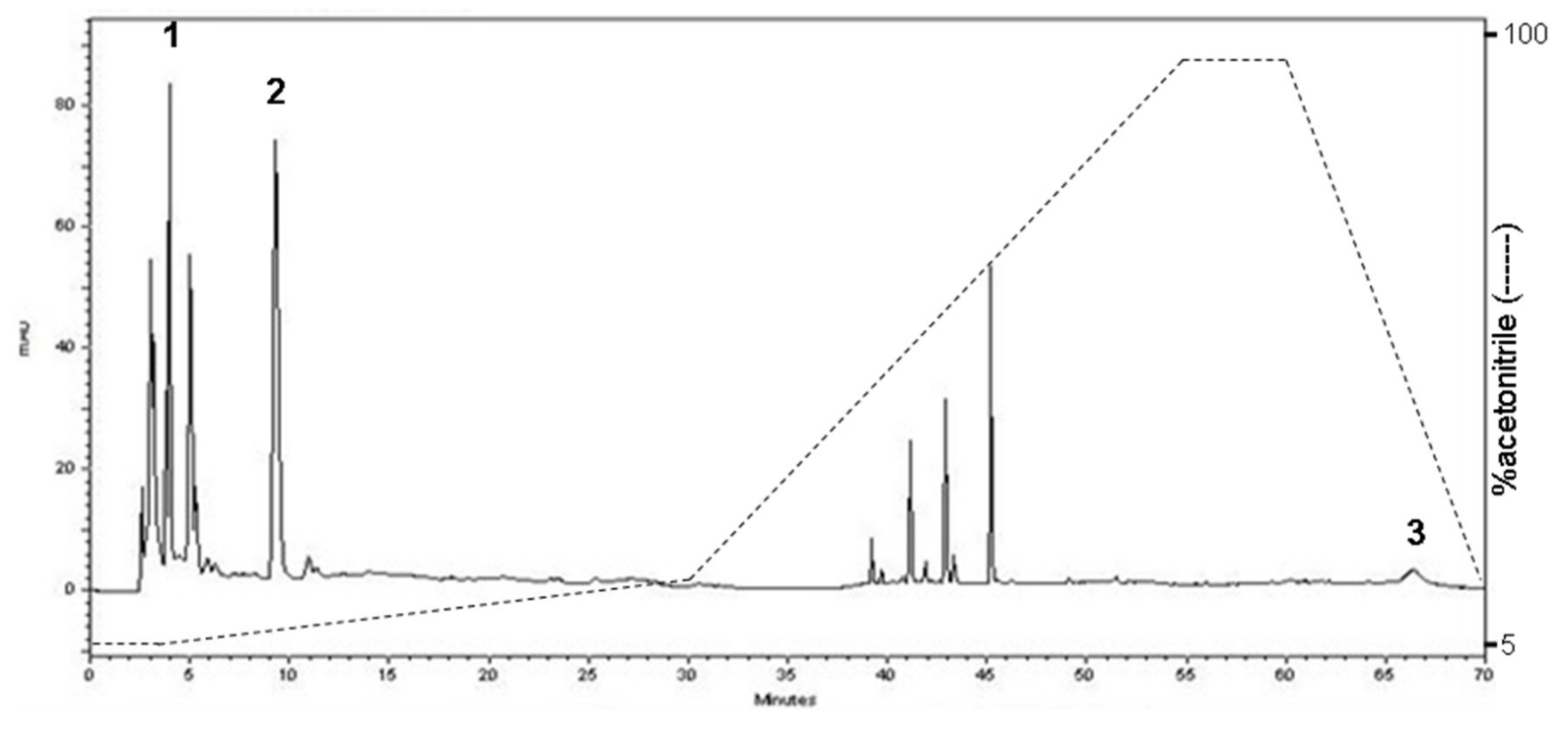

Figure 1: High performance liquid chromatography (HPLC) chromatogram of $\boldsymbol{C}$. sinensis. The quantification of samples was performed using a Shimadzu SCL-10A VP HPLC system comprising a gradient pump and the column used the PAK $\mathrm{C}_{18}, 5 \mu \mathrm{m}(250$ $\times 4.6 \mathrm{~mm}$ ) maintained at ambient room temperatures. 1: uridine (RT: $4.22 \mathrm{~min}$ ) 2: adenosine (RT: $9.48 \mathrm{~min})$ 3: ergosterol (RT: $66.16 \mathrm{~min}$ ). 


\section{Inhibitory effects of $C$. sinensis on DEN-induced} serum AST and ALT activities

As depicted in Figures 2A and 2B, serum AST and ALT activities were significantly promoted under DEN exposure compared with the healthy reference values, indicating that DEN caused severe hepatic cell injury. Treatment with $C$. sinensis almost completely abolished the increase of serum ALT and AST activities at 17 weeks, suggesting that $C$. sinensis could effectively inhibit DENinduced liver cell damage.

\section{Histological examination of the liver}

To determine the protective effect of $C$. sinensis against hepatic carcinoma in vivo, histological changes in the liver tissues of rats were examined by using haematoxylin-eosin $(\mathrm{H} / \mathrm{E})$ staining. In the DEN-treated group at 17 weeks $(17 \mathrm{~W})$, the nodules were separated by thick fibrous bands with varying degrees of cellular differentiation and lymphocyte infiltration (Figure 3a) whereas $C$. sinensis administration obviously alleviated these pathological changes and showed normal liver
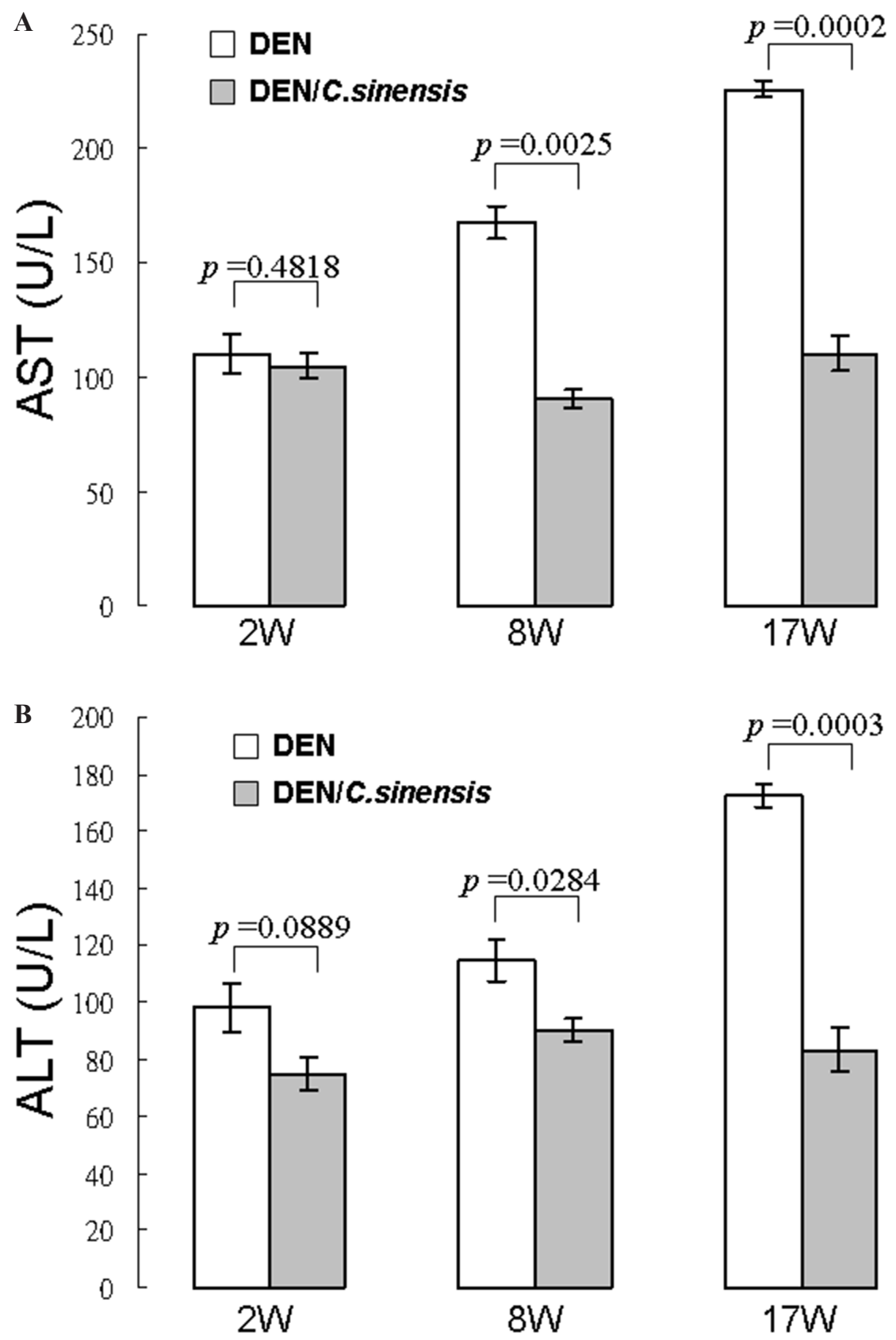

Figure 2: Effects of herbs on serum parameters with respect to liver functions of rats treated with DEN or DEN/C. sinensis. A. Determination of aspartate aminotransferase (AST) and B. alanine aminotransferase (ALT) at 2 week (2 W), 8 week (8 W) and 17 week $(17 \mathrm{~W})$, respectively using an Autodry Chemistry Analyzer. Rat's reference data: AST 39 111 U/L; ALT 20 61 U/L. Data are means \pm SD of repeated experiments. 
histology with well-developed and orderly arranged hepatocytes (Figure 3b). In addition, the liver tissue from the group exposed to DEN for 2 weeks $(2 \mathrm{~W})$ showed almost intact lobular architecture with central veins and radiating hepatic cords while the samples administrated with DEN for 8 weeks $(8 \mathrm{~W}$ ) had moderate fibrogenesis. Again, C. sinensis application could also restore the pathological changes at $2 \mathrm{~W}$ and $8 \mathrm{~W}$ (Supplement Figure 1). These results were consistent with the findings of AST/ ALT. The development of liver tumors as a consequence of DEN exposure was also characterized by the presence of altered hepatic foci stained positively for B23 using immunohistochemistry. Under microscopic examination, the exposure of DEN induced a substantial number of B23 positive foci (Figure 3c). In contrast, no B23 signal was detected in specimens treated with $C$. sinensis, indicating a strong protection of $C$. sinensis against DEN-induced hepatocarcinogenesis (Figure 3d).

\section{Proteomic analysis of differential protein profiles and identification by MALDI-MS}

To further understand the intracellular events and tumor growth inhibitory mechanism following 17 weeks of treatment with $C$. sinensis, high-resolution 2-DE, together with MALDI-MS, was used to reveal the global protein changes. Figure 4A demonstrates the typical gel image of the control sample. More than 1108 protein spots were shown by silver staining. Figure 4B presents close-up views of interesting 2-DE regions, and a computer-assisted analysis of the respective protein spots revealed 30 protein spots with significant and meaningful changes as indicated by Arabic numerals. Spots showing significantly altered expression levels were excised from gels and subjected to a PMF analysis after MALDI-TOF. Table 1 summarizes the detailed results using MASCOT database searching. Results in repeated experiments were consistent and reproducible. Western blot analysis was performed to verify the protein expression derived from proteome results. In accordance with the 2-DE profiles, endoplasmin (spot 1), cystathionine (spot 17), and CAIII (spot 26) were significantly increased under DEN/C. sinensis application compared with DEN treatment, while GSTPi (spot 28), Catalase (spot 7), COMT (spot 5), a-SMA (spot 3) showed obvious reduction after DEN/C. sinensis exposure (Figure 4C).

\section{Common and differential pathways activated among different treatment groups}

The network was generated using the shortest path algorithm to map interactions among root proteins identified in the experiment. Map Editor was used to build the network based on 30 key proteins in the
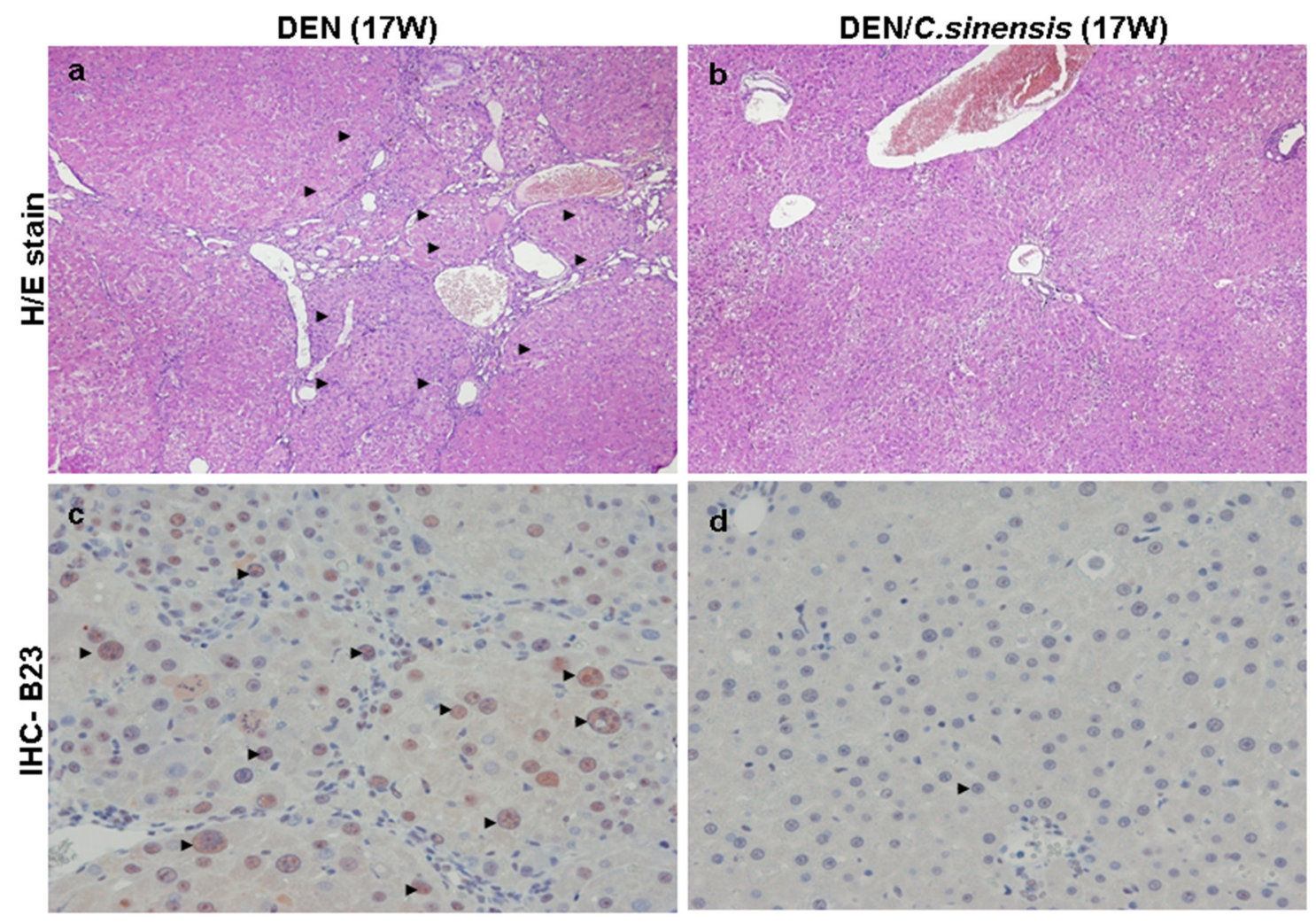

Figure 3: Histologic examination of rat liver at 17 week $(17 \mathrm{~W})$ by hematoxylin and eosin $(\mathrm{H} / \mathrm{E})$ staining and immunohistochemical staining for a. \& c. DEN-treated group, b. \& d. DEN/C. sinensis-treated group. The regions with differently expressed B23 were indicated by black arrows. Original magnification: 200×. 


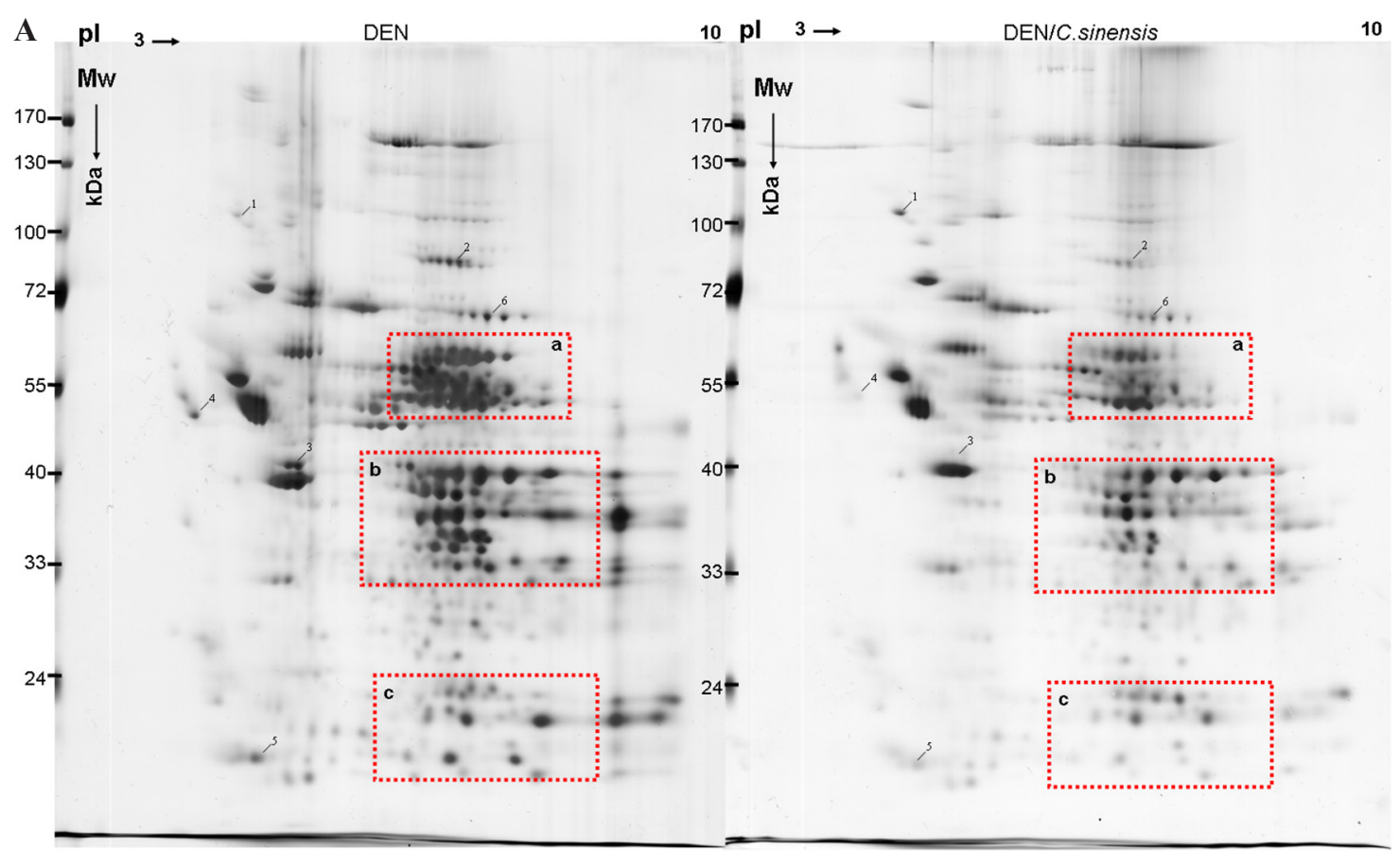

B

DEN

DEN/C.sinensis
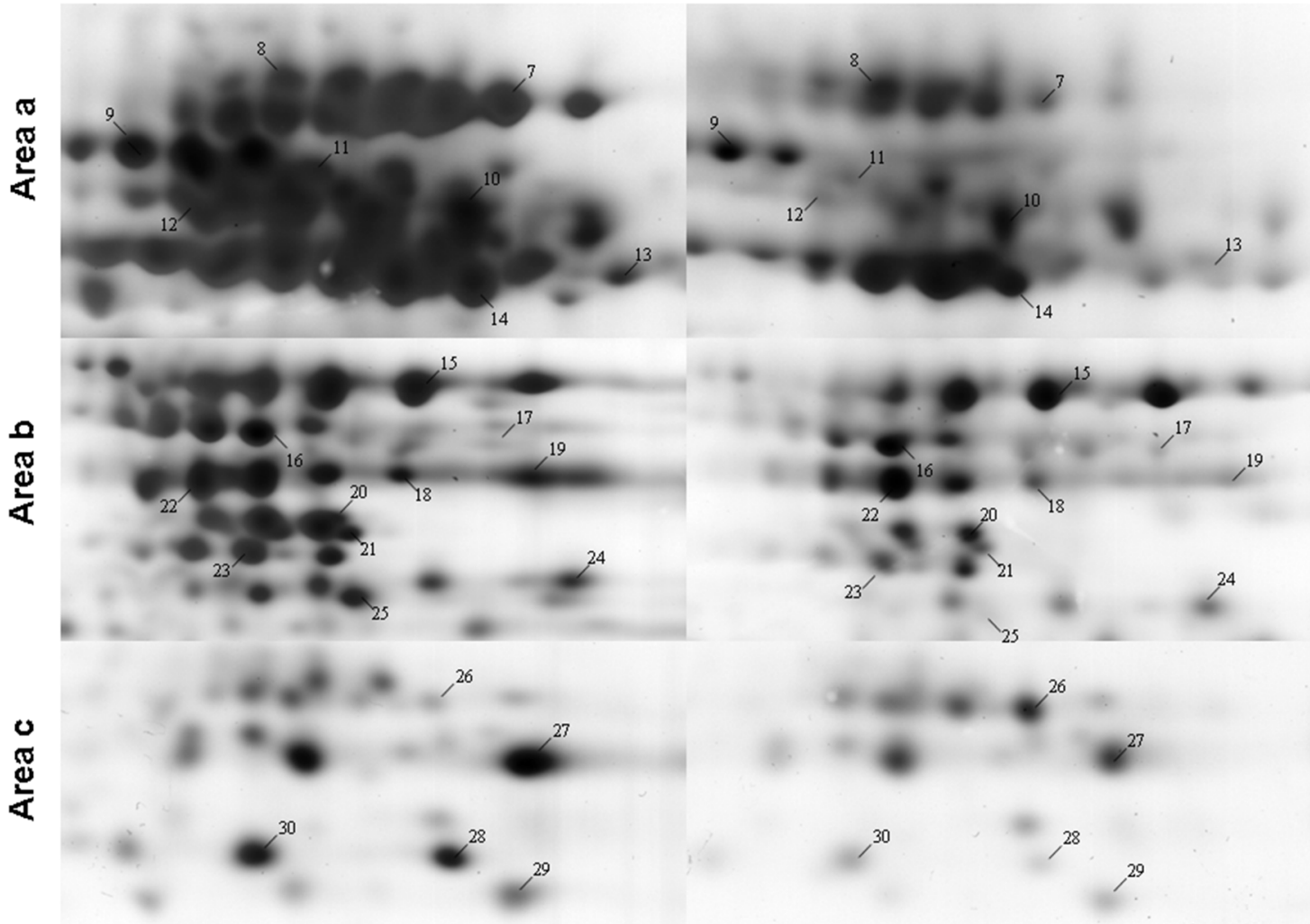

Figure 4: Comparison of 2-DE protein profiles of rat liver samples from DEN or DEN/C. sinensis groups. A. Protein lysate was focused on a linear 3-10 IPG strip and then separated with the SDS-PAGE. Each spot volume was determined and quantified as the intensity derived from the silver-staining. The red rectangular regions emphasize the differently expressed proteins with meaningful changes B. Close-up figures show changes in the levels of protein expression between the DEN and DEN/C. sinensis-treated groups. Protein spots with meaningful changes in intensity are labeled with Arabic numerals.

(Continued) 
C

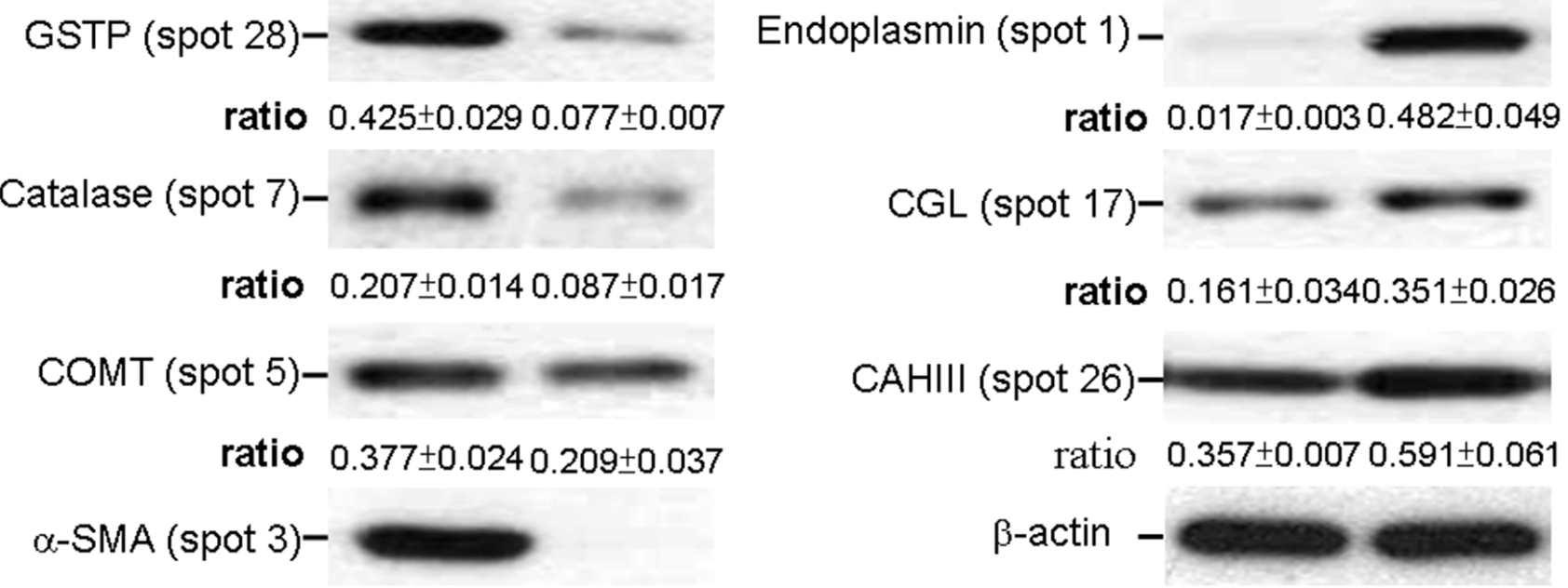

ratio $0.656 \pm 0.0460 .005 \pm 0.001$
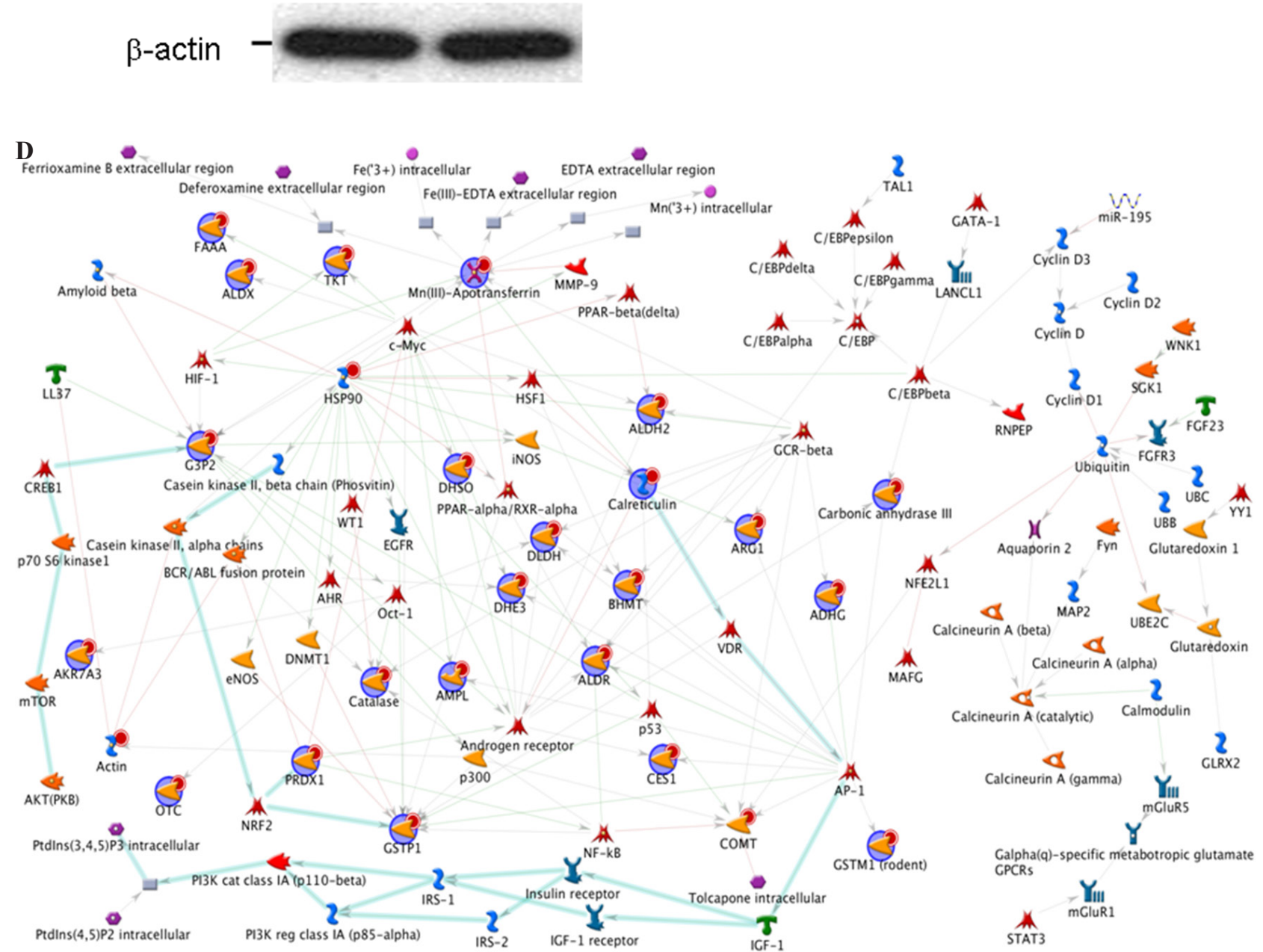

Figure 4 (Continued): C. Western blot analysis was applied to validate protein changes revealed by 2-DE analysis and $\beta$-actin was used as an internal control. The relative expression ratio to $\beta$-actin is shown at the bottom. D. Biological network analyses of differentially expressed proteins using MetaCore ${ }^{\mathrm{TM}}$ mapping tools. Nodes represent proteins and lines between the nodes indicate direct protein-protein interactions. The various proteins on this map are indicated by different symbols representing the functional class of the proteins.

(Continued) 
$\mathbf{E}$
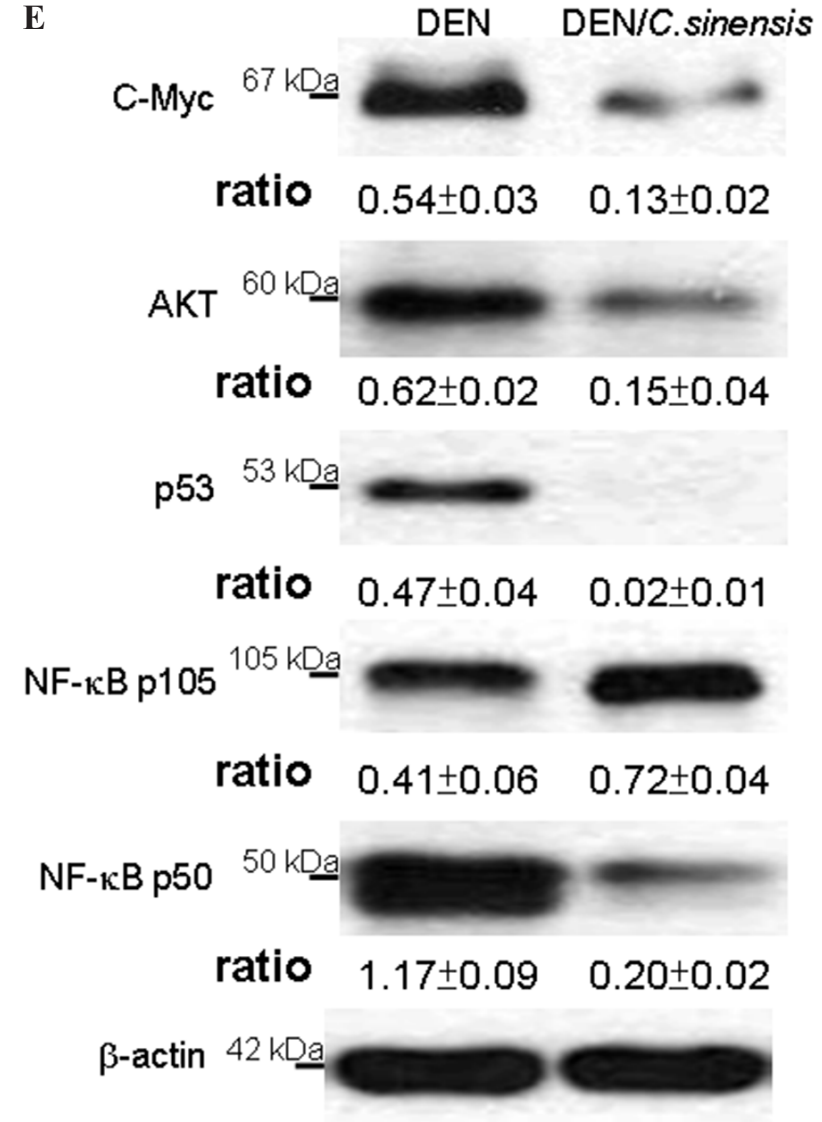

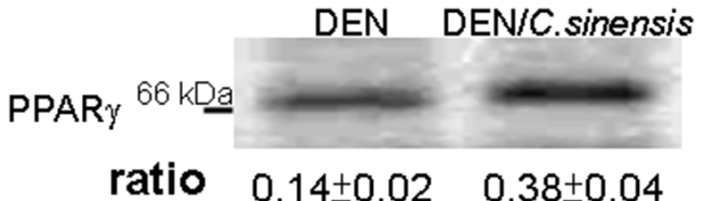

ratio $\quad 0.14 \pm 0.02 \quad 0.38 \pm 0.04$

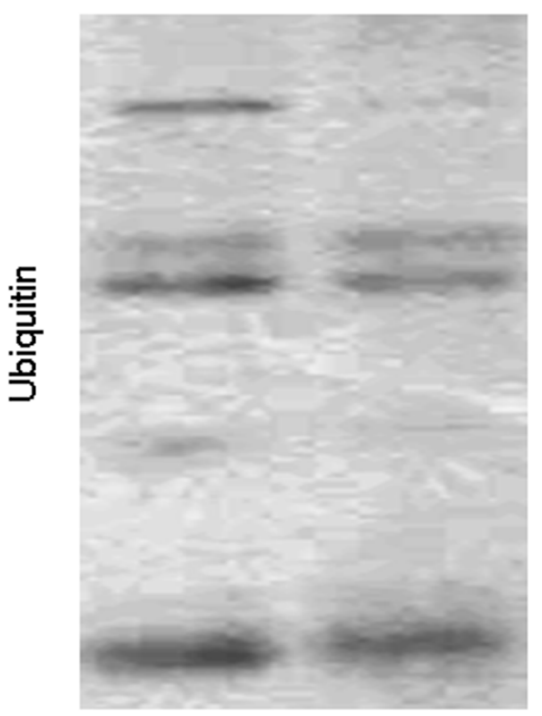

ratio $\quad 0.38 \pm 0.04 \quad 0.14 \pm 0.01$

$\beta$-actin $42 \mathrm{kDa}$

Figure 4 (Continued): E. The results derived from network analyses were confirmed by Western blot experiment and $\beta$-actin was used as an internal control. The relative expression ratio to $\beta$-actin is shown at the bottom.

C. sinensis-associated network. Highlighted lines represent specific, designated pathways. Background lines represented secondary, related biological pathways. According to the network, DEN disturbed the redox balance and sequentially activated ubiquitinproteasomal proteolysis cascades responsible for cellular stress responses. At the same time, DEN promoted the expression level of AKT, which should elicit a strong effect on cell proliferation as well as growth of HCC (Figure 4D). To ascertain the results revealed by the network analysis, Western blotting was applied to determine the expression of targeted proteins. In parallel, C. sinensis treatment attenuated DEN-induced ubiquitin and inhibited the level of C-Myc, AKT, p53 and NF$\kappa \mathrm{B}$ p50. In addition, PPAR $\gamma$ was obviously activated in response to DEN/C. sinensis compared to DEN administration (Figure 4E).

\section{Functional network analysis}

To further assess the global interaction of the differentially expressed proteins revealed by the proteome analysis and their significance in the possible mechanisms associated with the anti-tumor effects of $C$. sinensis, the targeted proteins were analyzed with the MetaCore analytical tool. The biological networks were built based on uploaded proteins, and the biological process was applied to each network, as shown in Figure 5A. The enrichment networks indicated that proteins differentially expressed after exposure to $C$. sinensis were predominantly involved in the response to hypoxia and oxidative stress $\left(p=2.508 \times 10^{-7}\right)$. The $p$-value indicates significance of the assigned GO process on the basis of assembly size as compared with the subnetworks derived from the input protein list.

According to above findings, the specific signaling proteins associated with ROS generation should be implied in the mechanisms by which C. sinensis could effectively restore DEN-caused hepatic damage. CYPOR and NQO1, the redox partners of cytochrome P450s which contribute to antioxidation and detoxification [24], were examined. Further, antioxidant genes HIF-1, HO-1 and Nrf-2 were also evaluated [25]. Western blot analysis was performed using antibodies against several signaling proteins regarding ROS generation. We detected markedly decreased NQO1 and obviously increased CYPOR, HIF-1, HO-1 and Nrf2 in the DEN/C. sinensis-treated group with respect to the DEN-applied group (Figure 5B). 
Table 1: List of differentially expressed protein spots (DEN/C. sinensis versus DEN extract)

\begin{tabular}{|c|c|c|c|c|c|c|c|c|c|}
\hline $\begin{array}{l}\text { Spot } \\
\text { No. }\end{array}$ & $\begin{array}{l}\text { Protein } \\
\text { Name }\end{array}$ & $\begin{array}{l}\text { Swiss- } \\
\text { Port No }\end{array}$ & pI & $\begin{array}{c}\text { Mw } \\
(\mathbf{k D a})\end{array}$ & $\begin{array}{c}\text { Score } \\
\text { (Coverag) }\end{array}$ & $\begin{array}{l}\text { Matched } \\
\text { Peptides }\end{array}$ & $\begin{array}{c}\text { Fold } \\
\text { change }^{\mathrm{a}}\end{array}$ & $\begin{array}{c}p \text { - } \\
\text { value }\end{array}$ & Function \\
\hline 1 & Endoplasmin & Q66HD0 & 4.72 & 92.99 & $139(33 \%)$ & 26 & $3.8 \pm 0.2$ & 0.04 & $\begin{array}{l}\text { Molecular chaperone } \\
\text { that functions in the } \\
\text { processing and transport } \\
\text { of secreted proteins. }\end{array}$ \\
\hline 2 & Serotransferrin & P12346 & 7.14 & 78.51 & $209(41 \%)$ & 31 & $-2.8 \pm 0.3$ & 0.02 & $\begin{array}{l}\text { Serum transferrin may } \\
\text { have a further role } \\
\text { in stimulating cell } \\
\text { proliferation. }\end{array}$ \\
\hline 3 & Actin & P62738 & 5.29 & 42.07 & $197(72 \%)$ & 23 & $-4.5 \pm 0.2$ & 0.03 & $\begin{array}{l}\text { Actins are highly } \\
\text { conserved proteins that } \\
\text { are involved in various } \\
\text { types of cell motility } \\
\text { and are ubiquitously } \\
\text { expressed in all } \\
\text { eukaryotic cells. }\end{array}$ \\
\hline 4 & Calreticulin & P18418 & 4.33 & 48.14 & $95(20 \%)$ & 10 & $-2.9 \pm 0.5$ & 0.05 & $\begin{array}{l}\text { Calcium-binding } \\
\text { chaperone that } \\
\text { promotes folding, } \\
\text { oligomeric assembly and } \\
\text { quality control in the } \\
\text { endoplasmic reticulum } \\
\text { (ER) via the calreticulin/ } \\
\text { calnexin cycle. }\end{array}$ \\
\hline 5 & $\begin{array}{c}\text { Catechol } \\
\text { O-methyltransferase } \\
(\mathrm{COMT})\end{array}$ & P22734 & 5.11 & 24.96 & $115(53 \%)$ & 10 & $-2.1 \pm 0.2$ & 0.03 & $\begin{array}{l}\text { Catalyzes the } \\
\text { O-methylation, and } \\
\text { thereby the inactivation, } \\
\text { of catecholamine } \\
\text { neurotransmitters and } \\
\text { catechol hormones. }\end{array}$ \\
\hline 6 & Transketolase & P50137 & 7.54 & 71.94 & $150(52 \%)$ & 25 & $-2.6 \pm 0.1$ & 0.02 & $\begin{array}{l}\text { Catalyzes the transfer of } \\
\text { a two-carbon ketol group } \\
\text { from a ketose donor to } \\
\text { an aldose acceptor, via } \\
\text { a covalent intermediate } \\
\text { with the cofactor } \\
\text { thiamine pyrophosphate. }\end{array}$ \\
\hline 7 & Catalase & P04762 & 7.07 & 60.06 & $225(53 \%)$ & 30 & $-3.7 \pm 0.1$ & 0.01 & $\begin{array}{l}\text { Occurs in almost all } \\
\text { aerobically respiring } \\
\text { organisms and serves } \\
\text { to protect cells from the } \\
\text { toxic effects of hydrogen } \\
\text { peroxide. }\end{array}$ \\
\hline 8 & $\begin{array}{c}\text { Liver } \\
\text { carboxylesterase } 4\end{array}$ & Q64573 & 6.29 & 62.63 & $137(54 \%)$ & 23 & $-4.5 \pm 0.2$ & 0.02 & $\begin{array}{l}\text { Involved in the } \\
\text { detoxification of } \\
\text { xenobiotics and in the } \\
\text { activation of ester and } \\
\text { amide prodrugs. }\end{array}$ \\
\hline 9 & $\begin{array}{c}\text { Carboxylesterase } \\
\text { 1D }\end{array}$ & P16303 & 6.10 & 62.39 & $78(25 \%)$ & 15 & $-2.6 \pm 0.1$ & 0.03 & $\begin{array}{l}\text { Involved in the } \\
\text { metabolism of } \\
\text { xenobiotics and of } \\
\text { natural substrates. }\end{array}$ \\
\hline
\end{tabular}

(Continued) 


\begin{tabular}{|c|c|c|c|c|c|c|c|c|c|}
\hline $\begin{array}{l}\text { Spot } \\
\text { No. }\end{array}$ & $\begin{array}{l}\text { Protein } \\
\text { Name }\end{array}$ & $\begin{array}{l}\text { Swiss- } \\
\text { Port No }\end{array}$ & pI & $\begin{array}{c}\text { Mw } \\
(\mathrm{kDa})\end{array}$ & $\begin{array}{c}\text { Score } \\
\text { (Coverag) }\end{array}$ & $\begin{array}{l}\text { Matched } \\
\text { Peptides }\end{array}$ & $\begin{array}{c}\text { Fold } \\
\text { change }^{\mathrm{a}}\end{array}$ & $\begin{array}{c}p- \\
\text { value }\end{array}$ & Function \\
\hline 10 & $\begin{array}{l}\text { Methylmalonate- } \\
\text { semialdehyde } \\
\text { dehydrogenase }\end{array}$ & Q02253 & 8.44 & 58.22 & $147(40 \%)$ & 19 & $-2.5 \pm 0.2$ & 0.02 & $\begin{array}{l}\text { Plays a role in valine and } \\
\text { pyrimidine metabolism. }\end{array}$ \\
\hline 11 & $\begin{array}{l}\text { Dihydrolipoyl } \\
\text { dehydrogenase }\end{array}$ & Q6P6R2 & 7.96 & 54.57 & $113(45 \%)$ & 21 & $-4.0 \pm 0.1$ & 0.02 & $\begin{array}{c}\text { Lipoamide } \\
\text { dehydrogenase is a } \\
\text { component of the glycine } \\
\text { cleavage system as } \\
\text { well as of the alpha- } \\
\text { ketoacid dehydrogenase } \\
\text { complexes. }\end{array}$ \\
\hline 12 & $\begin{array}{l}\text { Cytosol } \\
\text { aminopeptidase }\end{array}$ & Q68FS4 & 6.77 & 56.51 & $129(47 \%)$ & 20 & $-3.5 \pm 0.2$ & 0.03 & $\begin{array}{l}\text { Presumably involved } \\
\text { in the processing and } \\
\text { regular turnover of } \\
\text { intracellular proteins. } \\
\text { Catalyzes the removal of } \\
\text { unsubstituted N-terminal } \\
\text { amino acids from various } \\
\text { peptides }\end{array}$ \\
\hline 13 & $\begin{array}{c}\text { Aldehyde } \\
\text { dehydrogenase }\end{array}$ & P11884 & 6.69 & 56.08 & $125(55 \%)$ & 20 & $-1.6 \pm 0.1$ & 0.02 & $\begin{array}{c}\text { An aldehyde }+\mathrm{NAD}^{+}+ \\
\mathrm{H}_{2} \mathrm{O}=\text { a carboxylate }+ \\
\text { NADH. }\end{array}$ \\
\hline 14 & $\begin{array}{c}\text { Glutamate } \\
\text { dehydrogenase } 1\end{array}$ & P10860 & 8.05 & 61.72 & $188(58 \%)$ & 34 & $-1.2 \pm 0.3$ & 0.04 & $\begin{array}{c}\text { Mitochondrial glutamate } \\
\text { dehydrogenase that } \\
\text { converts L-glutamate } \\
\text { into alpha-ketoglutarate. }\end{array}$ \\
\hline 15 & $\begin{array}{l}\text { Betaine--homocysteine } \\
\text { S-methyltransferase } 1\end{array}$ & O09171 & 8.01 & 45.40 & $156(65 \%)$ & 24 & $-1.8 \pm 0.1$ & 0.01 & $\begin{array}{l}\text { Involved in the } \\
\text { regulation of } \\
\text { homocysteine } \\
\text { metabolism. } \\
\text { Converts betaine } \\
\text { and homocysteine to } \\
\text { dimethylglycine and } \\
\text { methionine, respectively. }\end{array}$ \\
\hline 16 & Fumarylacetoacetase & P25093 & 6.67 & 46.23 & $155(57 \%)$ & 25 & $-1.1 \pm 0.2$ & 0.03 & $\begin{array}{l}\text { 4-fumarylacetoacetate } \\
+\mathrm{H}_{2} \mathrm{O}=\text { acetoacetate }+ \\
\text { fumarate }\end{array}$ \\
\hline 17 & $\begin{array}{l}\text { Cystathionine gamma- } \\
\text { lyase (CGL) }\end{array}$ & P18757 & 7.94 & 44.24 & $126(56 \%)$ & 16 & $1.5 \pm 0.3$ & 0.04 & $\begin{array}{l}\text { Catalyzes the last step } \\
\text { in the trans-sulfuration } \\
\text { pathway from } \\
\text { methionine to cysteine. }\end{array}$ \\
\hline 18 & $\begin{array}{c}\text { Sorbitol } \\
\text { dehydrogenase }\end{array}$ & P27867 & 6.83 & 38.79 & $86(53 \%)$ & 14 & $-2.2 \pm 0.4$ & 0.05 & $\begin{array}{l}\text { Converts sorbitol to } \\
\text { fructose. Part of the } \\
\text { polyol pathway that } \\
\text { plays an important role } \\
\text { in sperm physiology. }\end{array}$ \\
\hline 19 & $\begin{array}{c}\text { Alcohol } \\
\text { dehydrogenase } 1\end{array}$ & P06757 & 8.52 & 40.53 & $96(42 \%)$ & 13 & $-2.5 \pm 0.1$ & 0.02 & $\begin{array}{c}\text { An alcohol }+\mathrm{NAD}^{+}= \\
\text {an aldehyde or ketone }+ \\
\text { NADH. }\end{array}$ \\
\hline
\end{tabular}

(Continued) 


\begin{tabular}{|c|c|c|c|c|c|c|c|c|c|}
\hline $\begin{array}{l}\text { Spot } \\
\text { No. }\end{array}$ & $\begin{array}{l}\text { Protein } \\
\text { Name }\end{array}$ & $\begin{array}{l}\text { Swiss- } \\
\text { Port No }\end{array}$ & pI & $\begin{array}{c}\text { Mw } \\
(\mathrm{kDa})\end{array}$ & $\begin{array}{c}\text { Score } \\
\text { (Coverag) }\end{array}$ & $\begin{array}{l}\text { Matched } \\
\text { Peptides }\end{array}$ & $\begin{array}{c}\text { Fold } \\
\text { change }^{\mathrm{a}}\end{array}$ & $\begin{array}{c}p- \\
\text { value }\end{array}$ & Function \\
\hline 20 & $\begin{array}{c}\text { Aflatoxin B1 } \\
\text { aldehyde } \\
\text { reductase member } 3\end{array}$ & P38918 & 6.83 & 37.12 & $103(46 \%)$ & 17 & $-3.6 \pm 0.2$ & 0.01 & $\begin{array}{l}\text { Can reduce the } \\
\text { dialdehyde protein- } \\
\text { binding form of } \\
\text { aflatoxin B1 (AFB1) to } \\
\text { the non-binding AFB1 } \\
\text { dialcohol. Probably } \\
\text { involved in protection } \\
\text { of liver against the } \\
\text { toxic and carcinogenic } \\
\text { effects of AFB1, a potent } \\
\text { hepatocarcinogen. }\end{array}$ \\
\hline 21 & $\begin{array}{c}\text { Alcohol } \\
\text { dehydrogenase } \\
{\left[\mathrm{NADP}^{+}\right]}\end{array}$ & P51635 & 6.84 & 36.71 & $112(51 \%)$ & 18 & $-2.0 \pm 0.1$ & 0.02 & $\begin{array}{l}\text { Catalyzes the NADPH- } \\
\text { dependent reduction of } \\
\text { a variety of aromatic } \\
\text { and aliphatic aldehydes } \\
\text { to their corresponding } \\
\text { alcohols. Plays a role } \\
\text { in the activation of } \\
\text { procarcinogens, such } \\
\text { as polycyclic aromatic } \\
\text { hydrocarbon trans- } \\
\text { dihydrodiols, and in the } \\
\text { metabolism of various } \\
\text { xenobiotics and drugs }\end{array}$ \\
\hline 22 & Arginase-1 & P07824 & 6.76 & 35.12 & $120(57 \%)$ & 18 & $-2.8 \pm 0.2$ & 0.02 & $\begin{array}{l}\text { L-arginine }+\mathrm{H}_{2} \mathrm{O}= \\
\text { L-ornithine }+ \text { urea. }\end{array}$ \\
\hline 23 & $\begin{array}{c}\text { Ornithine } \\
\text { carbamoyltransferase }\end{array}$ & P00481 & 9.12 & 39.92 & $165(53 \%)$ & 25 & $-3.4 \pm 0.1$ & 0.04 & $\begin{array}{l}\text { Carbamoyl phosphate }+ \\
\text { L-ornithine }=\text { phosphate } \\
\quad+\text { L-citrulline. }\end{array}$ \\
\hline 24 & $\begin{array}{l}\text { Glyceraldehyde- } \\
\text { 3-phosphate } \\
\text { dehydrogenase }\end{array}$ & P04797 & 8.43 & 36.10 & $65(45 \%)$ & 10 & $-1.9 \pm 0.1$ & 0.01 & $\begin{array}{l}\text { Has both glyceraldehyde- } \\
\text { 3-phosphate } \\
\text { dehydrogenase and } \\
\text { nitrosylase activities, } \\
\text { thereby playing a role in } \\
\text { glycolysis and nuclear } \\
\text { functions, respectively. }\end{array}$ \\
\hline 25 & Aldose reductase & P07943 & 7.08 & 36.51 & $106(61 \%)$ & 19 & $-2.4 \pm 0.1$ & 0.02 & $\begin{array}{l}\text { Catalyzes the NADPH- } \\
\text { dependent reduction of a } \\
\text { wide variety of carbonyl- } \\
\text { containing compounds } \\
\text { to their corresponding } \\
\text { alcohols with a broad } \\
\text { range of catalytic } \\
\text { efficiencies. }\end{array}$ \\
\hline 26 & $\begin{array}{c}\text { Carbonic anhydrase } 3 \\
\text { (CAHIII) }\end{array}$ & P14141 & 6.89 & 29.70 & $174(79 \%)$ & 24 & $1.9 \pm 0.2$ & 0.02 & $\begin{array}{l}\text { Reversible hydration of } \\
\text { carbon dioxide. A major } \\
\text { participant in the liver } \\
\text { response to oxidative } \\
\text { stress. }\end{array}$ \\
\hline
\end{tabular}

(Continued) 


\begin{tabular}{|c|c|c|c|c|c|c|c|c|c|}
\hline $\begin{array}{l}\text { Spot } \\
\text { No. }\end{array}$ & $\begin{array}{l}\text { Protein } \\
\text { Name }\end{array}$ & $\begin{array}{l}\text { Swiss- } \\
\text { Port No }\end{array}$ & pI & $\begin{array}{c}\text { Mw } \\
\text { (kDa) }\end{array}$ & $\begin{array}{c}\text { Score } \\
\text { (Coverag) }\end{array}$ & $\begin{array}{l}\text { Matched } \\
\text { Peptides }\end{array}$ & $\begin{array}{c}\text { Fold } \\
\text { change }^{\mathrm{a}}\end{array}$ & $\begin{array}{c}p- \\
\text { value }\end{array}$ & Function \\
\hline 27 & $\begin{array}{c}\text { Glutathione } \\
\text { S-transferase } \mathrm{Mu} 2\end{array}$ & P08010 & 6.90 & 25.87 & $208(86 \%)$ & 28 & $-2.6 \pm 0.1$ & 0.04 & $\begin{array}{l}\text { Conjugation of } \\
\text { reduced glutathione } \\
\text { to a wide number } \\
\text { of exogenous and } \\
\text { endogenous hydrophobic } \\
\text { electrophiles. }\end{array}$ \\
\hline 28 & $\begin{array}{c}\text { Glutathione } \\
\text { S-transferase P } \\
\text { (GSTP) }\end{array}$ & P04906 & 6.89 & 23.65 & $95(54 \%)$ & 10 & $-2.1 \pm 0.1$ & 0.01 & $\begin{array}{l}\text { Conjugation of } \\
\text { reduced glutathione } \\
\text { to a wide number } \\
\text { of exogenous and } \\
\text { endogenous hydrophobic } \\
\text { electrophiles. }\end{array}$ \\
\hline 29 & Peroxiredoxin-1 & Q63716 & 8.27 & 22.32 & $127(69 \%)$ & 12 & $-1.4 \pm 0.1$ & 0.02 & $\begin{array}{l}\text { Involved in redox } \\
\text { regulation of the cell. } \\
\text { Reduces peroxides with } \\
\text { reducing equivalents } \\
\text { provided through the } \\
\text { thioredoxin system but } \\
\text { not from glutaredoxin. }\end{array}$ \\
\hline 30 & $\begin{array}{c}\text { Glutathione } \\
\text { S-transferase Mu } 1\end{array}$ & P04905 & 7.63 & 26.13 & $228(81 \%)$ & 24 & $-3.1 \pm 0.2$ & 0.02 & $\begin{array}{l}\text { Conjugation of } \\
\text { reduced glutathione } \\
\text { to a wide number } \\
\text { of exogenous and } \\
\text { endogenous hydrophobic } \\
\text { electrophiles. }\end{array}$ \\
\hline
\end{tabular}

(a) $p$-values were generated by analyzing the gel images using Prodigy SameSpots ${ }^{\mathrm{TM}}$ software. These values are representative of C.S./DEN compared to DEN samples. Differences were considered significant at * $p<0.05$.

\section{Verification of the protein carbonylation}

The aforementioned results indicated that oxidationassociated cascades should contribute to the etiology of DEN-induced hepatoma and the tumor-inhibitory efficacy of $C$. sinensis. Network analysis suggested that oxidative stress has been implicated as one of the leading causes of hepatocarcinoma induced by DEN. Carbonylation of proteins due to oxidative modification has been shown to affect their function in various metabolic processes. Changes in oxidized proteins between DEN-treated and $\mathrm{DEN} / C$. sinensis-applied groups were detected by $2-\mathrm{DE}$ oxyblots. As expected, the extent of oxidation in chaperone proteins and specific enzymes, including $\mathrm{HSC} 7 \mathrm{C}$ (Heat shock cognate $71 \mathrm{kDa}$ protein), GRP75 (glucose-regulated protein 75), GRP78, propionyl-CoA carboxylase, catalase, and alpha-enolase, dramatically increased in the DENtreated samples. As expected, there was a remarkably decreasing tendency toward protein oxidation in the $\mathrm{DEN} / C$. sinensis-exposed group, indicating that $C$. sinensis could effectively scavenge ROS generated by DEN and in turn sequester hepatic tumor development (Figure 5C). To validate the 2-DE oxyblot results, the carbonylated levels of the proteins were determined by post-Western blot derivatization after immunoprecipitation
(Supplement Figure 2). Grp78, Grp75 and CAHIII (Carbonic anhydrase 3) were immunoprecipitated with respective antibodies and Western-blotted with anti-DNP antibodies. The carbonyl levels of these proteins were consistent with the aforementioned 2-DE oxyblot findings. Table 2 lists the significantly carbonylated proteins separated by 2-DE analysis. These results suggested that C. sinensis might prevent DEN-triggered carcinogenesis through amending ROS-caused abnormalities of specific pathways.

\section{DISCUSSION}

Current therapy for liver carcinoma is usually hindered due to the lack of effective techniques and therapeutic strategies. A great number of conventional medicines have been applied to liver diseases, and some herbal remedies have been useful in the management of hepatic tumors [26, 27].

DEN has hepatic carcinogen and mutagen properties and leads to various liver pathological characteristics [28, 29]. Our results showed that $C$. sinensis could significantly alleviate DEN-induced serum aminotransferases, implying that $C$. sinensis could protect the liver from chemical 


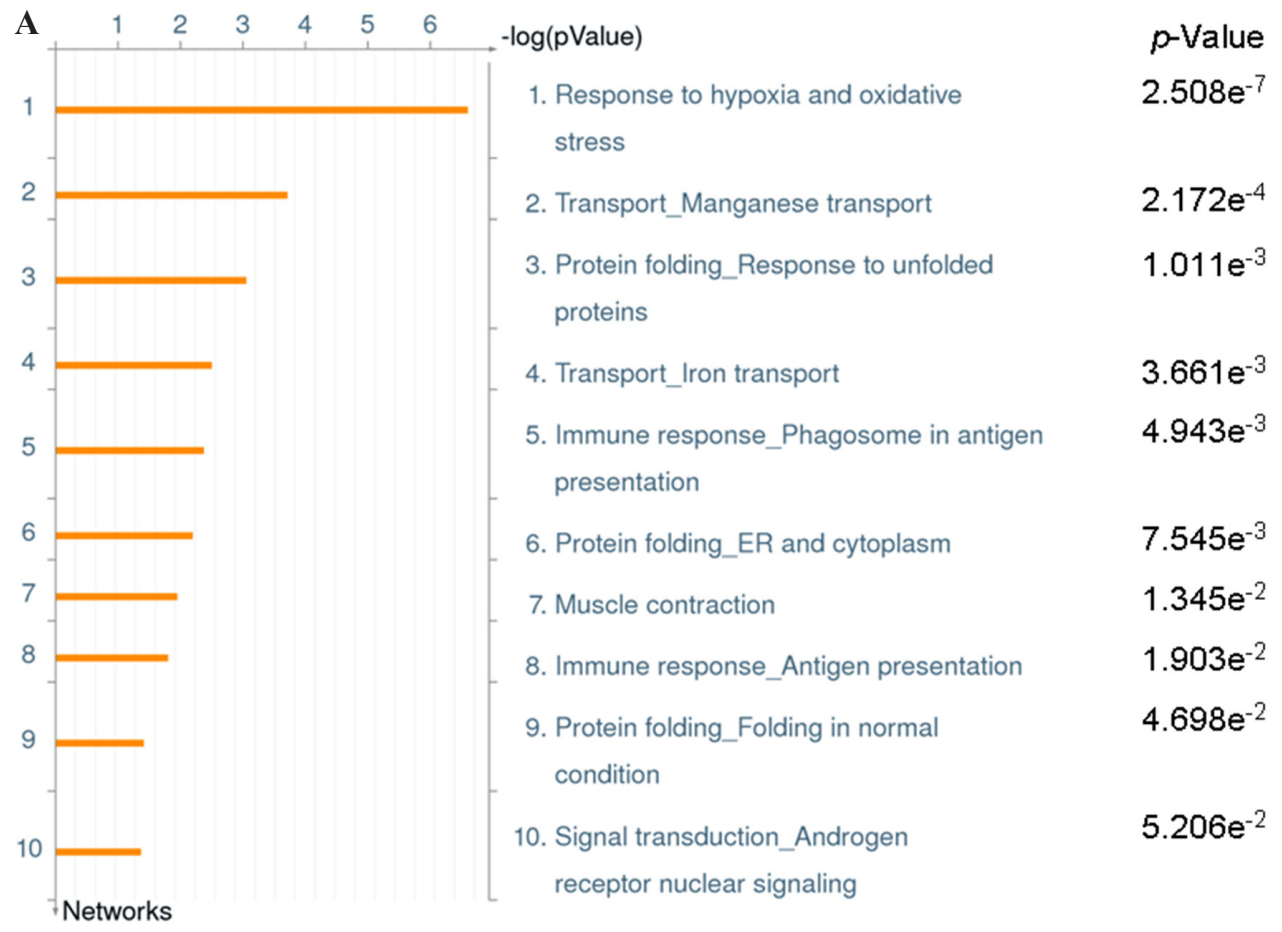

B

DEN DEN/C.sinensis

CYPOR $76 \mathrm{kDa}$

ratio $\quad 0.15 \pm 0.03 \quad 0.56 \pm 0.02$

NQO1 ${ }^{31 \mathrm{kDa}}$

ratio

$0.73 \pm 0.04 \quad 0.04 \pm 0.01$

HIF-1 $32 \mathrm{kDa}$

ratio $\quad 0.32 \pm 0.05 \quad 0.86 \pm 0.06$

HO-1 32 kDa

ratio $\quad 0.24 \pm 0.08 \quad 0.44 \pm 0.05$

$\mathrm{Nrf2}$

$57 \mathrm{kDa}$

ratio $\quad 0.02 \pm 0.01 \quad 0.47 \pm 0.04$

$\beta$-actin

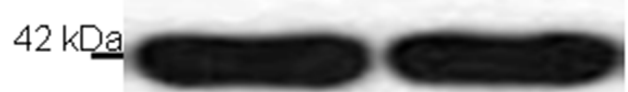

Figure 5: A. Top-ranked pathways from the GeneGO MetaCore ${ }^{\mathrm{TM}}$ pathway analysis. Pathways were ranked according to $p$ values, and bars represent the inverse log of the $p$ value. B. The levels of protein targets correlated with oxidative stress were performed by Western blot analysis. $\beta$-actin was used as an internal control. The relative expression ratio to $\beta$-actin is shown at the bottom.

(Continued) 


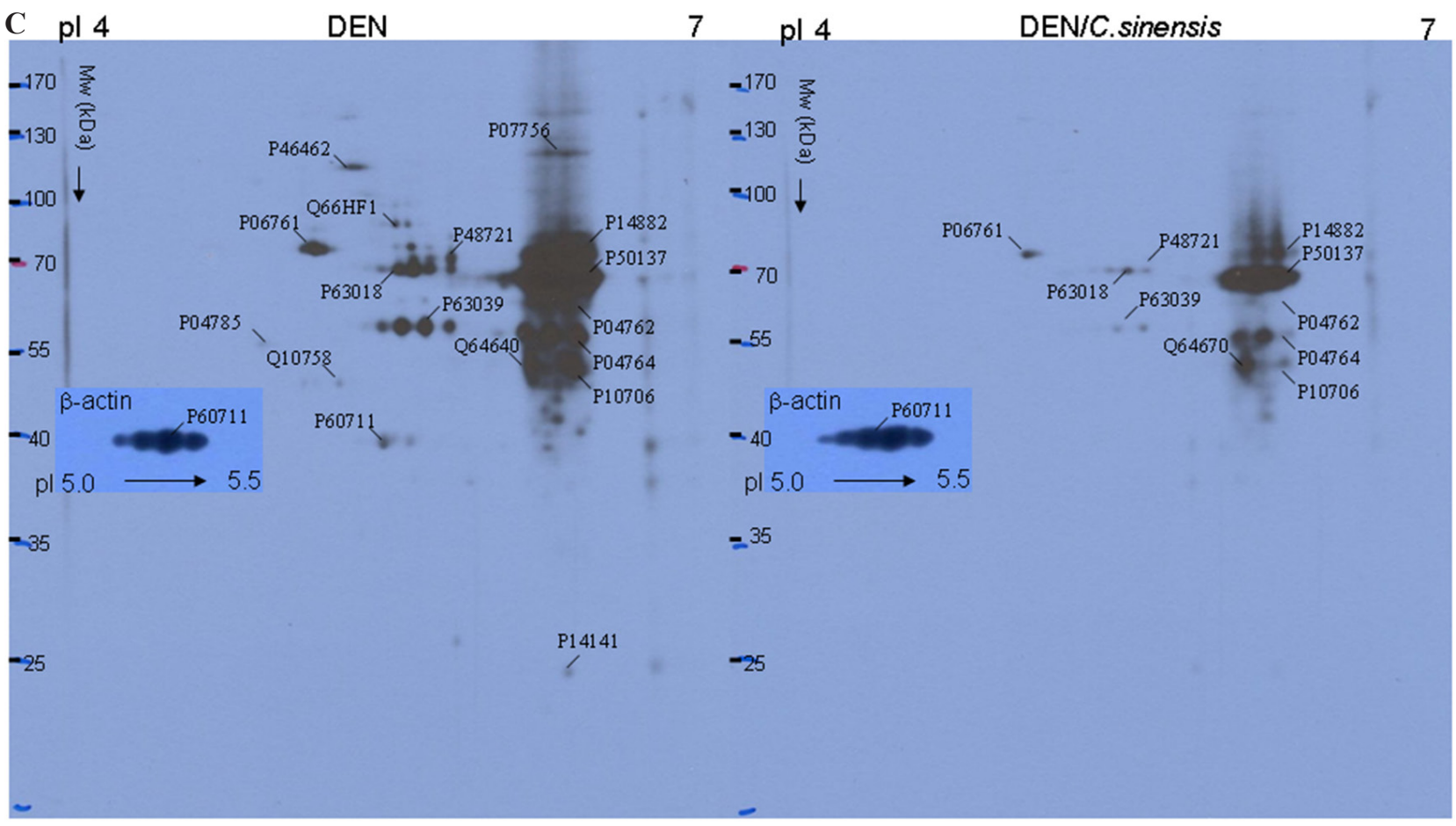

Figure 5 (Continued): C. Images of the 2-DE oxyblot. Analysis of protein oxidation levels in DNP-derivatized cellular proteins between DEN and DEN/C. sinensis treatments. Obvious reduction in the carbonylation levels of proteins are observed in the $C$. sinensis-treated group compared to DEN group. Equal amount of $\beta$-actin protein indicates that the loading volume of protein for both groups is the same.

exposure and toxicity. In addition, nucleophosmin (B23) is known to be subject to cell death counteraction. It is expressed weakly in hepatocytes whereas it is highly expressed in hepatocellular carcinomas (HCC) with a tight association between enhanced B23 expression and increased tumor grading [30]. Again, C. sinensis treatment strongly abolished the B23-positive lesions elicited by DEN, suggesting that $C$. sinensis should be effective in inhibiting DEN-induced growth of malignant cells.

Proteome analysis has revealed 30 protein spots displaying significant alterations with or without $C$. sinensis treatment in the presence of DEN. These proteins were grouped into several categories according to their known functions with Process network analysis. Several ROS-related proteins, including catalase, DHE3 (Glutamate dehydrogenase 1), PRDX1 (Peroxiredoxin-1), GSTP (Glutathione S-transferase P), GSTM1 and GSTM2, showed impressive changes in volume under C. sinensis exposure. All these enzymes are critical in the antioxidant defense, especially in hepatic cells. In this regard, oxidative stress caused by DEN would promote the protein expression level, whereas the application of $C$. sinensis could eliminate the ROS, resulting in a significant reduction of the level of redox state-correlated proteins [31]. Moreover, the major compounds of $C$. sinensis contain adenosine, uridine and ergosterol. These bioactive components could effectively suppress ROS generation and promote antioxidant capacity, which therefore may protect cells against oxidative stress- induced injuries [32, 33].
It is well established that protein oxidation and ROS production are tightly linked to a series of pathological events; the oxidative modification of certain key molecules is sufficient to initiate tumor progression [34, 35]. As expected, 2-DE oxyblots have demonstrated that the extent of oxidation in chaperone proteins and some enzymes, including HSC71, GRP75, GRP78, propionylCoA carboxylase, catalase, and alpha-enolase, was remarkably promoted in the DEN-treated group. Thus, the physiological function of carbonylated proteins becomes impaired and results in the sequential hepatocarcinoma. Conversely, $C$. sinensis is beneficial in preventing proteins from carbonylation, implying that $C$. sinensis could protect cells against carcinogenesis via increasing antioxidant capacity [36].

According to the results, the most striking feature is that catalase showed significant changes in quality and quantity under different treatments. DEN administration induced the expression of antioxidant enzymes to eradicate $\mathrm{H}_{2} \mathrm{O}_{2}$ as well as other free radicals whereas catalase was highly oxidized in DEN-treated samples compared to DEN/C. sinensis group. Hence, the activity of catalase may be impaired or abolished under oxidative modification leading to accumulation of oxidative stress and misfolding proteins, which is responsible for the hepatic carcinogenesis [37]. In this regard, C. sinensis is effective in protecting liver from oxidative damage through maintaining the function of antioxidant enzymes. In addition, GRP75 and GRP78 
Table 2: List of differentially expressed oxidized protein spots

\begin{tabular}{|c|c|c|c|c|c|c|}
\hline Protein Name & $\begin{array}{l}\text { Swiss- } \\
\text { Port No }\end{array}$ & pI & $\begin{array}{c}\text { Mw } \\
(\mathbf{k D a})\end{array}$ & $\begin{array}{c}\text { Score } \\
\text { (Coverag) }\end{array}$ & $\begin{array}{l}\text { Matched } \\
\text { Peptides }\end{array}$ & Function \\
\hline $\begin{array}{l}\text { Carbamoyl-phosphate } \\
\text { synthase }\end{array}$ & P07756 & 6.33 & 165.7 & $246(36 \%)$ & 44 & $\begin{array}{l}\text { Involved in the urea cycle of ureotelic } \\
\text { animals where the enzyme plays an } \\
\text { important role in removing excess } \\
\text { ammonia from the cell. }\end{array}$ \\
\hline $\begin{array}{l}\text { Transitional endoplasmic } \\
\text { reticulum ATPase }\end{array}$ & P46462 & 5.14 & 89.85 & $213(48 \%)$ & 31 & $\begin{array}{l}\text { Necessary for the fragmentation of } \\
\text { Golgi stacks during mitosis and for their } \\
\text { reassembly after mitosis. Component of } \\
\text { the } \mathrm{VCP} / \mathrm{p} 97-\mathrm{AMFR} / \mathrm{gp} 78 \text { complex that } \\
\text { participates in the final step of the sterol- } \\
\text { mediated ubiquitination and endoplasmic } \\
\text { reticulum-associated degradation } \\
\text { (ERAD) of HMGCR. }\end{array}$ \\
\hline $\begin{array}{l}\text { Propionyl-CoA carboxylase } \\
\text { alpha chain }\end{array}$ & P14882 & 6.65 & 80.53 & $102(25 \%)$ & 18 & $\begin{array}{l}\mathrm{ATP}+\text { propanoyl-CoA }+\mathrm{HCO}_{3}^{-}=\mathrm{ADP}+ \\
\text { phosphate }+(\mathrm{S}) \text {-methylmalonyl-CoA. }\end{array}$ \\
\hline $\begin{array}{l}\text { GRP78 ( } 78 \text { kDa glucose- } \\
\text { regulated protein) }\end{array}$ & P06761 & 5.07 & 72.47 & $288(57 \%)$ & 35 & $\begin{array}{l}\text { Probably plays a role in facilitating } \\
\text { the assembly of multimeric protein } \\
\text { complexes inside the endoplasmic } \\
\text { reticulum. }\end{array}$ \\
\hline $\begin{array}{l}\text { NADH dehydrogenase } \\
\text { (ubiquinone) Fe-S protein } 1\end{array}$ & Q66HF1 & 5.65 & 80.31 & $101(28 \%)$ & 14 & $\begin{array}{l}\text { Core subunit of the mitochondrial } \\
\text { membrane respiratory chain NADH } \\
\text { dehydrogenase (Complex I) that is } \\
\text { believed to belong to the minimal } \\
\text { assembly required for catalysis. Complex } \\
\text { I functions in the transfer of electrons } \\
\text { from NADH to the respiratory chain. }\end{array}$ \\
\hline $\begin{array}{l}\text { GRP75 ( } 75 \text { kDa glucose- } \\
\text { regulated protein) }\end{array}$ & P48721 & 5.87 & 73.98 & $119(41 \%)$ & 20 & $\begin{array}{l}\text { Implicated in the control of cell } \\
\text { proliferation and cellular aging. May also } \\
\text { act as a chaperone. }\end{array}$ \\
\hline $\begin{array}{l}\text { HSP7C (Heat shock } \\
\text { cognate } 71 \text { kDa protein) }\end{array}$ & P63018 & 5.43 & 71.06 & $199(58 \%)$ & 29 & $\begin{array}{c}\text { Participates in the ER-associated } \\
\text { degradation (ERAD) quality control } \\
\text { pathway in conjunction with J domain- } \\
\text { containing co-chaperones and the E3 } \\
\text { ligase CHIP (By similarity). }\end{array}$ \\
\hline $\begin{array}{l}\text { CH60 ( } 60 \mathrm{kDa} \text { heat shock } \\
\text { protein) }\end{array}$ & P63039 & 5.35 & 58.06 & $192(57 \%)$ & 21 & $\begin{array}{l}\text { mplicated in mitochondrial protein } \\
\text { import and macromolecular assembly. }\end{array}$ \\
\hline Cytokeratin-8 & Q10758 & 5.49 & 52.68 & $180(53 \%)$ & 26 & $\begin{array}{l}\text { Together with KRT19, helps to link the } \\
\text { contractile apparatus to dystrophin at the } \\
\text { costameres of striated muscle. }\end{array}$ \\
\hline $\begin{array}{l}\text { PDIA1 (Protein disulfide- } \\
\text { isomerase) }\end{array}$ & P04785 & 4.87 & 54.38 & $147(51 \%)$ & 19 & $\begin{array}{l}\text { This multifunctional protein catalyzes the } \\
\text { formation, breakage and rearrangement } \\
\text { of disulfide bonds. }\end{array}$ \\
\hline Serum albumin & P02770 & 6.09 & 70.67 & $240(51 \%)$ & 29 & $\begin{array}{l}\text { Its main function is the regulation of the } \\
\text { colloidal osmotic pressure of blood. }\end{array}$ \\
\hline Catalase & P04762 & 7.07 & 60.06 & $218(54 \%)$ & 26 & $\begin{array}{l}\text { Occurs in almost all aerobically respiring } \\
\text { organisms and serves to protect cells } \\
\text { from the toxic effects of hydrogen } \\
\text { peroxide. Promotes growth of cells. }\end{array}$ \\
\hline
\end{tabular}

(Continued) 


\begin{tabular}{|c|c|c|c|c|c|c|}
\hline Protein Name & $\begin{array}{l}\text { Swiss- } \\
\text { Port No }\end{array}$ & pI & $\begin{array}{l}\text { Mw } \\
\text { (kDa) }\end{array}$ & $\begin{array}{c}\text { Score } \\
\text { (Coverag) }\end{array}$ & $\begin{array}{l}\text { Matched } \\
\text { Peptides }\end{array}$ & Function \\
\hline Alpha-enolase & P04764 & 6.16 & 47.31 & $95(52 \%)$ & 15 & $\begin{array}{l}\text { Multifunctional enzyme that, as well } \\
\text { as its role in glycolysis, plays a part in } \\
\text { various processes such as growth control, } \\
\text { hypoxia tolerance and allergic responses. }\end{array}$ \\
\hline$\beta$-actin & P60711 & 5.31 & 42.11 & $184(67 \%)$ & 23 & $\begin{array}{l}\text { Actins are highly conserved proteins } \\
\text { that are involved in various types of cell } \\
\text { motility and are ubiquitously expressed } \\
\text { in all eukaryotic cells. }\end{array}$ \\
\hline Adenosine kinase & Q64640 & 5.84 & 40.45 & $97(32 \%)$ & 13 & $\begin{array}{l}\text { Serves as a potential regulator of } \\
\text { concentrations of extracellular adenosine } \\
\text { and intracellular adenine nucleotides. }\end{array}$ \\
\hline Adenosylhomocysteinase & P10760 & 6.08 & 47.89 & $143(51 \%)$ & 19 & $\begin{array}{l}\text { Adenosylhomocysteinase may play a } \\
\text { key role in the control of methylations } \\
\text { via regulation of the intracellular } \\
\text { concentration of adenosylhomocysteine. }\end{array}$ \\
\hline $\begin{array}{l}\text { CAH3 (Carbonic anhydrase } \\
\text { 3) }\end{array}$ & P14141 & 6.89 & 29.69 & $154(72 \%)$ & 21 & $\begin{array}{l}\text { Reversible hydration of carbon dioxide. } \\
\text { A major participant in the liver response } \\
\text { to oxidative stress. }\end{array}$ \\
\hline
\end{tabular}

which function as chaperone in protein folding, had no obvious alteration in volume. However, 2-DE oxyblot revealed that both GRP75 and GRP78 are highly carbonylated under DEN application and suggested a significant relationship between loss of function of chaperone proteins and the clinicopathological features of hepatoma [38].

Highly oxidized proteins caused by DEN finally lead to accumulation of misfolding proteins and subsequent endoplasmic reticulum (ER) stress, which in turn activates the ubiquitin-proteasome pathway (UPP) involves in the cellular processes such as the cell cycle, signal transduction, DNA repair and apoptosis [39]. Our results showed that increased expression of ubiquitin protein was observed in DEN-exposed samples compared to the DEN/C. sinensis group, indicating that the UPP should be implicated in hepatic carcinogenesis. Meanwhile, our results indicated that C. sinensis could promote the levels of CYPOR and HIF-1. C. sinensis also induced the expression of $\mathrm{Nrf}-2$, increasing the expression of antioxidant enzymes, such as HO-1. As a result, $C$. sinensis can prevent DEN-caused oxidative damage by activating various proteins and transcription factors which exclude ROS-induced cytotoxicity. The antioxidant properties of $C$. sinensis make it a powerful hepatoprotective agent. Given that Nrf-2 knockout mice particularly showed enhanced DNA binding of NF- $\mathrm{KB}$, it is likely that ROS have been shown to activate NF- $\mathrm{kB}$ [40]. We report here that NF- $\mathrm{kB}$ p50, which promotes chemoresistance and tumorigenesis, was strongly suppressed by $C$. sinensis treatment under DEN stimulation.
Network analysis also dissected that p53 checkpoint as well as the specific oncogenes including c-myc and PI3K/Akt are most frequently involved in DEN-induced hepatocarinogenesis and the anti-cancer efficacy of C. sinensis. C-Myc is a transcription factor and well known oncogene that promotes cancer cell proliferation and essentially connects with cancer formation [41]. Here, C. sinensis treatment significantly abolished C-Myc overproduction caused by DEN. AKT is a well-known oncogenic kinase, and it is critical in cell survival as well as cancer development [42]. The functional and pathway analysis also evidenced that AKT/mTOR cascade was inhibited under $C$. sinensis exposure. p53 signaling molecules are highly interacted and induced by DEN, showing their importance during progression of hepatoma [43]. Peroxisome proliferatoractivated receptor- $\gamma$ (PPAR $\gamma)$ is a class of ligandactivated nuclear transcription factor. Extensive studies have shown that PPAR $\gamma$ could regulate lipid metabolism and cell inflammation, and that it also has a significant anti-tumor effect [44]. Therefore, PPAR $\gamma$ overexpression would block HCC cell proliferation and invasion [45]. Consistently, we have demonstrated that $C$. sinensis exposure could remarkably induce the expression of $\operatorname{PPAR} \gamma$, which was inhibited by DEN application, indicating that $C$. sinensis is a potent anti-tumor herbal medicine.

Overall, our research is the first to present that C. sinensis treatment has a potent effect on preventing DEN-induced hepatocarcinogenesis. The global 
comparison of protein profiles with or without $C$. sinensis administration in the presentation of DEN showed that $C$. sinensis could exert HCC-preventive efficacy via its antioxidant characteristic, which consequently maintains the stability of particular proteins and suppresses the oncogenes (Figure 6). Our findings facilitate a better understanding of the herbal drug's therapeutic effect on the molecular mechanisms in hepatocellular carcinoma.

\section{MATERIALS AND METHODS}

\section{Preparation of $C$. sinensis ethanol extract and constitutions analysis with HPLC}

The powder of $C$. sinensis was purchased from a traditional Chinese medicine dispensary (local pharmaceutical company, Taiwan) and ethanol $(8 \mathrm{~L} \times 7)$ was used to prepare primarily extracted solution which were then concentrated and lyophilized to yield brown syrup. The voucher specimen (CGU-CS-1) was deposited in the herbarium of Chang Gung University. A high-performance liquid chromatographic (Shimadzu SCL-10A VP) coupled with SPD-M10A VP diode array detector, was performed for qualitative determination of compounds in the extract [46]. Representative chromatogram of C. sinensis ethanolic extract and constituents were shown in Figure 1.

\section{Animal}

Male Lewis rats (150-200 g body wt) used for the experiments were obtained from the Animal Center at the National Cheng Kung University of Taiwan. The rats were randomly divided into 2 groups (DEN-treated and DEN/C. sinensis $12.5 \mathrm{mg} / \mathrm{Kg}$ body weight (B.W.)treated) according to their body weights, with 5 rats in each group kept in natural light at room temperature and were allowed free access to water and feed (Chang Gung Memorial Hospital, Kaohsiung). In the DEN-treated group, rats were fed an oral aqueous solution of DEN (Sigma Chemical Co., St. Louis, MO) 100 parts per million daily as their drinking water for 120 days [47]. In $\mathrm{DEN} / C$. sinensis group, animals were treated with DEN aqueous solution by oral route and ethanol extract of $C$. sinensis via animal-feeding tube concurrently for the 120 days, which was prepared as previously described [48]. Rats were humanely sacrificed under anesthesia with ether 24 hours after the last treatment
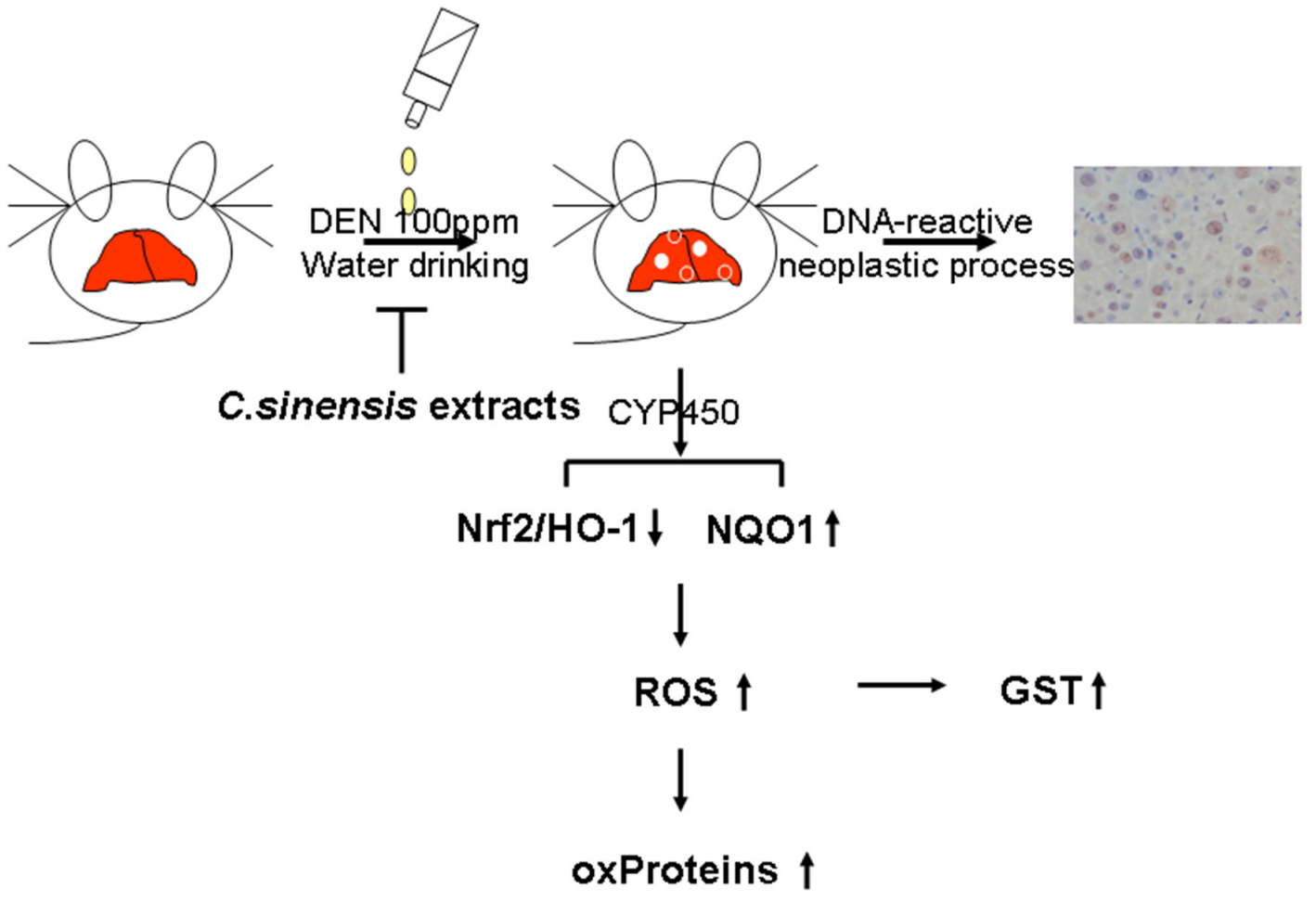

Ubiquitination $\longrightarrow$ AKT/C-Myc $\uparrow$

Figure 6: Schematic diagram indicates that $C$. sinensis could effectively inhibit the DEN-induced hepatic tumor through modulating the antioxidant systems and subsequent oxidative modification of specific proteins. 
with DEN. At the time of sacrifice, blood was collected via heart puncture for the isolation of serum. The liver was quickly removed, washed with PBS and weighed. Portions of the liver were collected separately for different analyses.

\section{Determination of serum enzymes}

The increase of serum alanine aminotransferase (ALT) and aspartate aminotransferase (AST) activities is widely used as an index for liver cell damage. In this study, activities of ALT and AST in rat serum were determined using an Abbott VP biochemical analyzer with respective test kits (Abbott Laboratory, Chicago, IL).

\section{Immunohistochemistry}

A piece of liver tissue fixed with 10\% neutralbuffered formalin was then embedded in paraffin and sliced into $5-\mu \mathrm{m}$ sections that were stained with $\mathrm{H} / \mathrm{E}$ for a histological assessment. Immunohistochemstry with nucleophosmin/B23 (1:100 dilutions in PBS) was applied to the specimens, as previously described [48]. The histological changes were evaluated by using optical microscopy (Olympus BX51, Japan) in nonconsecutive, randomly chosen $\times 200$ or $\times 400$ histological fields.

\section{Two-dimensional polyacrylamide gel electrophoresis (2-D PAGE)}

The protein extraction was prepared as follows. Small piece of frozen liver ( $20 \mathrm{mg})$ was solubilized in lysis buffer containing $7 \mathrm{M}$ urea, $2 \mathrm{M}$ thiourea, 4\% CHAPS, 2\% IPG buffer, $65 \mathrm{mM}$ DTT, $10 \mathrm{mM}$ PMSF and protease inhibitor cocktail (AMRESCO, Solon, OH, USA) and subjected to homogenize for 60 seconds on ice. The lysate was centrifuged at 10,000 rpm (Kubota 3500 , Japan) at $4^{\circ} \mathrm{C}$ for $20 \mathrm{~min}$ to remove insoluble material. The resultant supernatant was collected and the protein concentration was determined by Bradford assay (AMRESCO). $200 \mu \mathrm{g}$ of lysates were solubilized in the rehydration buffer and then separated by an 18 cm IPG strip on the IPGphor (GE Healthcare) in the first dimension. The running condition of the isoelectric focusing (IEF) was followed using our previous protocol [48, 49]. Following IEF separation and equilibration, electrophoresis was carried out on $10 \%$ acrylamide gels (Bio-Rad) until the bromophenol blue dye front reached the bottom of the gel. The gels were identified using a silver stain, and scanned using an ImageScanner (GE Healthcare). Protein spots were quantified using the Prodigy SameSpots software (Nonlinear Dynamics, UK). The expression levels of protein spots dysregulated $>1.5$ fold with statistical significance $(p$-value $<0.05)$ between $\mathrm{DEN}$ and $\mathrm{DEN} / C$. sinensis should be considered as proteins of interest. All experiments were repeated at least three times.

\section{D-Oxyblot}

Following isoelectric focusing, IPG strips were incubated in solution of $2 \mathrm{~N} \mathrm{HCl}$ with $10 \mathrm{mM} \mathrm{DNPH}$ at $25^{\circ} \mathrm{C}$ for $20 \mathrm{~min}$. After carbonyls derivatization step, strips were washed with $2 \mathrm{M}$ Tris-base $/ 30 \%$ glycerol for $15 \mathrm{~min}$ and then used for molecular weight dependent separation of proteins by acrylamide gels, followed by protein blotting to a membrane [50-52]. Next, this membrane was incubated overnight at $4^{\circ} \mathrm{C}$ with the primary antibody solution (Sigma, Missouri, USA) in the Tris-buffered saline Tween-20 (TBST) containing 5\% non-fat milk. The blots were then washed and incubated with goat anti-rabbit IgG/ HRP conjugate for $2 \mathrm{hr}$ at room temperature. Enhanced chemiluminescence (Millipore) was used for detection.

\section{In-gel enzymatic digestion and mass spectrometry}

Spots of interest were excised and in-gel digested with trypsin according to previously described procedures $[49,51]$. After digestion, the tryptic peptides were acidified with $0.5 \%$ TCA and loaded onto an MTP AnchorChip $^{\text {TM }}$ 600/384 TF (Bruker-Daltonik, Bremen, Germany). MS analysis was performed on an Ultraflex ${ }^{\mathrm{TM}}$ MALDI-TOF mass spectrometer (Bruker-Daltonik). Spectra were collected and calibrated by four point internal calibration (m/z 956.5355, 1296.6860, 1758.9335, 2465.198). Monoisotopic peptide masses were assigned and used for database searches with the MASCOT search engine (http://www.matrixscience.com) (Matrix Science, London). Search parameters were set as follows: a maximum allowed peptide mass error of $50 \mathrm{ppm}$, and consideration of one incomplete cleavage per peptide. For TOF/TOF, the three most intense precursor ions with a signal/noise ratio of $>25$ were selected after exclusion of common background signals [53].

\section{Western blot analysis}

The protein was separated with $10 \%$ SDS-PAGE and transferred to a membrane. Western blot analysis was performed as described previously, using COMT, GRP75, GRP78, CAHIII, Nrf2, PPAR, CYPOR, Cystathionine gamma-lyase, ubiquitin (Santa Cruz), Catalase, c-Myc, NF-кB, HIF-1, HO-1 (Epitomics), GSTP (Bethyl Lab), Endoplasmin, p53, AKT (Cell Signal), NQO1 (Proteintech), $\alpha$-SMA, $\beta$-actin and anti-DNP (Sigma) overnight at $4^{\circ} \mathrm{C}$., followed by incubated with HRPlabeled secondary antibody. Enhanced chemiluminescence was used for signal detection. Expression of $\beta$-actin was used to control for equal gel loading [54].

\section{Biological network analysis using MetaCore ${ }^{\mathrm{TM}}$}

To elucidate the ontological classes and relevant pathways represented among the proteins identified 
by 2-DE and the peptide mass fingerprint, we applied MetaCore $^{\mathrm{TM}}$ software (vers. 5.1 build 16271, GeneGo, St. Joseph, MI, USA). As a dataset, we converted all differentially detected proteins into accession numbers, together with their multiples of change, and uploaded these into MetaCore ${ }^{\mathrm{TM}}[49,55]$.

\section{Statistical analysis}

All values were presented as the mean \pm standard deviation (SD) of a minimum of 3 replicate tests obtained from three individual experiments. A Kruskal-Wallis (nonparametric ANOVA) test was carried out using SPSS software (SPSS, Inc, Chicago, IL, USA) when multiple comparisons were made.

\section{ACKNOWLEDGMENTS}

This work was supported by a grant from the National Science Council (NSC102-2628-B-182003-MY3) and Chang Gung Memorial Hospital (CMRPD1B0401 2, CMRPD1D0341 2, BMRP445), Taiwan.

\section{CONFLICTS OF INTEREST}

The authors declare no conflicts of interest.

\section{REFERENCES}

1. Forner A, Llovet JM, Bruix J. Hepatocellular carcinoma. Lancet. 2012; 379:1245-1255.

2. Sherman M. Hepatocellular carcinoma: epidemiology, risk factors, and screening. Semin Liver Dis. 2005; 25:143-154.

3. Berliner L, Lemke HU, vanSonnenberg E, Ashamalla H, Mattes MD, Dosik D, Hazin H, Shah S, Mohanty S, Verma S, Esposito G, Bargellini I, Battaglia V, Caramella D, Bartolozzi C, Morrison P. Model-guided therapy for hepatocellular carcinoma: a role for information technology in predictive, preventive and personalized medicine. EPMA J. 2014; 5:16

4. De Minicis S, Marzioni M, Benedetti A, Svegliati-Baroni G. New insights in hepatocellular carcinoma: from bench to bedside. Ann Transl Med. 2013; 1:15.

5. Aravalli RN, Cressman EN, Steer CJ. Cellular and molecular mechanisms of hepatocellular carcinoma: an update. Arch Toxicol. 2013; 87:227-247.

6. Hikita H, Kodama T, Tanaka S, Saito Y, Nozaki Y, Nakabori T, Shimizu S, Hayashi Y, Li W, Shigekawa M, Sakamori R, Miyagi T, Hiramatsu N, Tatsumi T, Takehara T. Activation of the Mitochondrial Apoptotic Pathway Produces Reactive Oxygen Species and Oxidative Damage in Hepatocytes That Contribute to Liver Tumorigenesis. Cancer Prev Res (Phila). 2015; 8:693-701.
7. Sasaki Y. Does oxidative stress participate in the development of hepatocellular carcinoma? J Gastroenterol. 2006; 41:1135-1148.

8. Cardin R, Piciocchi M, Bortolami M, Kotsafti A, Barzon L, Lavezzo E, Sinigaglia A, Rodriguez-Castro KI, Rugge M, Farinati F. Oxidative damage in the progression of chronic liver disease to hepatocellular carcinoma: an intricate pathway. World J Gastroenterol. 2014; 20:3078-3086.

9. Ng TB, Wang HX. Pharmacological actions of Cordyceps, a prized folk medicine. J Pharm Pharmacol. 2005; 57:1509-1519.

10. Liu Y, Wang J, Wang W, Zhang H, Zhang X, Han C. The Chemical Constituents and Pharmacological Actions of Cordyceps sinensis. Evid Based Complement Alternat Med. $2015 ; 2015: 575063$.

11. Lo HC, Hsieh C, Lin FY, Hsu TH. A Systematic Review of the Mysterious Caterpillar Fungus Ophiocordyceps sinensis in Dong-ChongXiaCao (Dōng Chóng Xià Căo) and Related Bioactive Ingredients. J Tradit Complement Med. 2013; 3:16-32.

12. Das SK, Masuda M, Sakurai A, Sakakibara M. Medicinal uses of the mushroom Cordyceps militaris: current state and prospects. Fitoterapia. 2010; 81:961-968.

13. Rao YK, Fang SH, Tzeng YM. Evaluation of the antiinflammatory and anti-proliferation tumoral cells activities of Antrodia camphorata, Cordyceps sinensis, and Cinnamomum osmophloeum bark extracts. J Ethnopharmacol. 2007; 114:78-85.

14. Reis FS, Barros L, Calhelha RC, Cirić A, van Griensven LJ, Soković M, Ferreira IC. The methanolic extract of Cordyceps militaris (L.) Link fruiting body shows antioxidant, antibacterial, antifungal and antihuman tumor cell lines properties. Food Chem Toxicol. 2013; 62:91-98.

15. Song J, Wang Y, Teng M, Zhang S, Yin M, Lu J, Liu Y, Lee RJ, Wang D, Teng L. Cordyceps militaris induces tumor cell death via the caspase-dependent mitochondrial pathway in HepG2 and MCF-7 cells. Mol Med Rep. 2016; 13:5132-5140.

16. Verna L, Whysner J, Williams GM. N-nitrosodiethylamine mechanistic data and risk assessment: bioactivation, DNAadduct formation, mutagenicity, and tumor initiation. Pharmacol Ther. 1996; 71:57-81.

17. Ha WS, Kim CK, Song SH, Kang CB. Study on mechanism of multistep hepatotumorigenesis in rat: development of hepatotumorigenesis. J Vet Sci. 2001; 2:53-58.

18. Paula Santos N, Colaço A, Gil da Costa RM, Manuel Oliveira M, Peixoto F, Alexandra Oliveira P. $\mathrm{N}$-diethylnitrosamine mouse hepatotoxicity: time-related effects on histology and oxidative stress. Exp Toxicol Pathol. 2014; 66:429-436.

19. Bingül İ, Başaran-Küçükgergin C, Tekkeşin MS, Olgaç V, Doğru-Abbasoğlu S, Uysal M. Effect of blueberry pretreatment on diethylnitrosamine-induced oxidative stress and liver injury in rats. Environ Toxicol Pharmacol. 2013; 36:529-538. 
20. Rogowska-Wrzesinska A, Wojdyla K, Nedić O, Baron CP, Griffiths HR. Analysis of protein carbonylation--pitfalls and promise in commonly used methods. Free Radic Res. 2014 Oct; 48:1145-62.

21. Ckless K. Redox proteomics: from bench to bedside. Adv Exp Med Biol. 2014; 806:301-17.

22. Unger FT, Witte I, David KA. Prediction of individual response to anticancer therapy: historical and future perspectives. Cell Mol Life Sci. 2015; 72:729-757.

23. Lee JM, Kohn EC. Proteomics as a guiding tool for more effective personalized therapy. Ann Oncol. 2010; 21:vii205-10.

24. Guise CP, Wang AT, Theil A, Bridewell DJ, Wilson WR, Patterson AV. Identification of human reductases that activate the dinitrobenzamide mustard prodrug PR-104A: a role for NADPH:cytochrome P450 oxidoreductase under hypoxia. Biochem Pharmacol. 2007; 74:810-820.

25. Singh M, Tulsawani R, Koganti P, Chauhan A, Manickam M, Misra K. Cordyceps sinensis increases hypoxia tolerance by inducing heme oxygenase- 1 and metallothionein via Nrf2 activation in human lung epithelial cells. Biomed Res Int. 2013; 2013:569206.

26. Luk JM, Wang X, Liu P, Wong KF, Chan KL, Tong Y, Hui CK, Lau GK, Fan ST. Traditional Chinese herbal medicines for treatment of liver fibrosis and cancer: from laboratory discovery to clinical evaluation. Liver Int. 2007; 27:879-890.

27. Wang X, Wang N, Cheung F, Lao L, Li C, Feng Y. Chinese medicines for prevention and treatment of human hepatocellular carcinoma: current progress on pharmacological actions and mechanisms. J Integr Med. 2015; 13:142-164.

28. Fausto N, Campbell JS. Mouse models of hepatocellular carcinoma. Semin Liver Dis. 2010; 30:87-98

29. Tolba R, Kraus T, Liedtke C, Schwarz M, Weiskirchen R. Diethylnitrosamine (DEN)-induced carcinogenic liver injury in mice. Lab Anim. 2015; 49:s59-69.

30. Yun JP, Miao J, Chen GG, Tian QH, Zhang CQ, Xiang J, $\mathrm{Fu}$ J, Lai PB. Increased expression of nucleophosmin/ B23 in hepatocellular carcinoma and correlation with clinicopathological parameters. Br J Cancer. 2007; 96:477-484.

31. Paula Santos N, Colaço A, Gil da Costa RM, Manuel Oliveira M, Peixoto F, Alexandra Oliveira P. N-diethylnitrosamine mouse hepatotoxicity: time-related effects on histology and oxidative stress. Exp Toxicol Pathol. 2014; 66:429-436.

32. Olatunji OJ, Feng Y, Olatunji OO, Tang J, Ouyang Z, Su Z, Wang D, Yu X. Neuroprotective effects of adenosine isolated from Cordyceps cicadae against oxidative and ER stress damages induced by glutamate in PC12 cells. Environ Toxicol Pharmacol. 2016; 44:53-61.

33. Pluchino LA, Liu AK, Wang HC. Reactive oxygen speciesmediated breast cell carcinogenesis enhanced by multiple carcinogens and intervened by dietary ergosterol and mimosine. Free Radic Biol Med. 2015; 80:12-26.

34. Marí M, Colell A, Morales A, von Montfort C, Garcia-Ruiz C, Fernández-Checa JC. Redox control of liver function in health and disease. Antioxid Redox Signal. 2010; 12:1295-1331.

35. Zhou S, Liu R, Yuan K, Yi T, Zhao X, Huang C, Wei Y. Proteomics analysis of tumor microenvironment: Implications of metabolic and oxidative stresses in tumorigenesis. Mass Spectrom Rev. 2013; 32:267-311.

36. Aguilar-Melero P, Ferrín G, Muntané J. Effects of nitric oxide synthase-3 overexpression on post-translational modifications and cell survival in HepG2 cells. J Proteomics. 2012; 75:740-755.

37. Mahawar M1, Tran V, Sharp JS, Maier RJ. Synergistic roles of Helicobacter pylori methionine sulfoxide reductase and GroEL in repairing oxidant-damaged catalase. J Biol Chem. 2011; 286:19159-19169.

38. Fang JY, Wang PW, Huang CH, Hung YY, Pan TL. Evaluation of the hepatotoxic risk caused by lead acetate via skin exposure using a proteomic approach. Proteomics. 2014; 14:2588-2599.

39. Tu Y, Chen C, Pan J, Xu J, Zhou ZG, Wang CY. The Ubiquitin Proteasome Pathway (UPP) in the regulation of cell cycle control and DNA damage repair and its implication in tumorigenesis. Int J Clin Exp Pathol. 2012; 5:726-738.

40. Köhler UA, Böhm F, Rolfs F, Egger M, Hornemann T, Pasparakis M, Weber A, Werner S. NF- $\mathrm{BB} /$ RelA and Nrf2 cooperate to maintain hepatocyte integrity and to prevent development of hepatocellular adenoma. J Hepatol. 2016; 64:94-102.

41. Buendia MA1, Bourre L, Cairo S. Myc target miRs and liver cancer: small molecules to get Myc sick. Gastroenterology. 2012; 142:214-218.

42. Bupathi M, Kaseb A, Meric-Bernstam F, Naing A. Hepatocellular carcinoma: Where there is unmet need. Mol Oncol. 2015; 9:1501-1509.

43. Charni M, Rivlin N, Molchadsky A, Aloni-Grinstein R, Rotter V. p53 in liver pathologies-taking the good with the bad. J Mol Med (Berl). 2014; 92:1229-1234.

44. Wu CW, Farrell GC, Yu J. Functional role of peroxisomeproliferator-activated receptor $\gamma$ in hepatocellular carcinoma. J Gastroenterol Hepatol. 2012; 27:1665-1669.

45. Kim KR, Choi HN, Lee HJ, Baek HA, Park HS, Jang KY, Chung MJ, Moon WS. A peroxisome proliferator-activated receptor gamma antagonist induces vimentin cleavage and inhibits invasion in high-grade hepatocellular carcinoma. Oncol Rep. 2007; 18:825-832.

46. Peng Y, Chen Q, Yang T, Tao Y, Lu X, Liu C. Cultured mycelium Cordyceps sinensis protects liver sinusoidal endothelial cells in acute liver injured mice. Mol Biol Rep. 2014; 41:1815-1827. 
47. Yano K, Fukuda Y, Sumimoto R, Ito H, Asahara T, Dohi $\mathrm{K}$. Development of a rat model for orthotopic liver transplantation for hepatocellular carcinoma. Surgery. 1995; 118:539-546.

48. Pan TL, Wang PW, Huang CH, Leu YL, Wu TH, Wu YR, You JS. Herbal formula, Scutellariae radix and Rhei rhizoma attenuate dimethylnitrosamine-induced liver fibrosis in a rat model. Sci Rep. 2015; 5:11734.

49. Pan TL, Hung YC, Wang PW, Chen ST, Hsu TK, Sintupisut N, Cheng CS, Lyu PC. Functional proteomic and structural insights into molecular targets related to the growth inhibitory effect of tanshinone IIA on HeLa cells. Proteomics. 2010; 10:914-929.

50. Madian AG, Regnier FE. Proteomic identification of carbonylated proteins and their oxidation sites. J Proteome Res. 2010; 9:3766-3780.

51. Hung YC, Wang PW, Pan TL. Functional proteomics reveal the effect of Salvia miltiorrhiza aqueous extract against vascular atherosclerotic lesions. Biochim Biophys Acta. 2010; 1804:1310-1321.
52. Kristensen BK, Askerlund P, Bykova NV, Egsgaard H, Møller IM. Identification of oxidised proteins in the matrix of rice leaf mitochondria by immunoprecipitation and two-dimensional liquid chromatography-tandem mass spectrometry. Phytochemistry. 2004; 65:1839-1851.

53. Pan TL, Wang PW, Huang CC, Goto S, Chen CL. Expression, by functional proteomics, of spontaneous tolerance in rat orthotopic liver transplantation. Immunology. 2004; 113:57-64.

54. Pan TL, Wang PW, Leu YL, Wu TH, Wu TS. Inhibitory effects of Scutellaria baicalensis extract on hepatic stellate cells through inducing G2/M cell cycle arrest and activating ERK-dependent apoptosis via Bax and caspase pathway. J Ethnopharmacol. 2012; 139:829-837.

55. Pan TL, Wang PW, Huang CC, Yeh CT, Hu TH, Yu JS. Network analysis and proteomic identification of vimentin as a key regulator associated with invasion and metastasis in human hepatocellular carcinoma cells. J Proteomics. 2012; 75:4676-4692. 